\title{
188 SAYILI ILO BALIKÇILIK İSTIHDAM SÖZLEŞMESİ IŞIĞINDA İş HUKUKUNDA BALIKÇILIK
}

\author{
Hatice Duygu ÖZER*
}

\section{$\ddot{O} Z$}

Balıkçılar, iş sözleşmesiyle çalı̧̧an ancak diğer çalışanlara göre farklı çalışma ortamı ve koşullarına tabi olan iş̧̧ilerdir. Yapmakta oldukları işin doğası gereği ortaya çıkan farklllık, bu grupta çalışanların hangi iş mevzuatına tabi olacakların belirlemede güçlük arz edebilmektedir. Çalışmamızda öncelikle balıkçılık faaliyetinin sinırları çizilerek, balıkçıların tabi olduğu hükümler değerlendirilecektir. Ardından uluslararası hukuk metinlerinde özellikle de ILO'nun 188 sayll Balıkçılık İstihdam Sözleşmesi'nde balıkçllı faaliyetini yürüten işçilerin çalışma yaşamından doğan haklarını düzenlemek için getirilen kurallar ele alınacaktır. Henüz ülkemizin taraf olmadı̆̆ yeni tarihli sözleşmede yer alan hükümlerle iç hukukumuzdaki balıkçılara ilişskin düzenlemeler klyaslanarak 188 sayılı ILO Sözleşmesinin ülkemiz mevzuatına olası katkları değerlendirilecektir. Çalı̧̧mamızın kapsamını çok genişletmemek için balıkçı gemilerinde çalışmak için aranan asgari koşullar konusu ile sınırlı tutulacaktır.

Anahtar Kelimeler: Balıkçıllk, 188 sayll ILO Sözleşmesi, Deniz İ̧̧ Hukuku, İş Hukuku, Gemiadamı

\section{FISHERIES IN LABOR LAW IN THE LIGHT OF ILO WORK IN FISHING CONVENTION NO. 188}

\section{ABSTRACT}

Fishermen are workers who work under a labor contract but are subject to different working conditions comparing with the other workers. This difference, which causes due to the nature of the work they are doing, may have difficulty in determining which labor legislation employees will be subject to. In this study, first of all, the limits of fishing activity will be drawn and the law to which they will be determined will be depend on accordingly. Then, international law texts, in particular the ILO's Work in Fishing Convention No. 188, will focus on the rules for regulating the rights of workers engaged in fishing. The possible contributions of the ILO Convention No. 188 to the legislation of our country will be evaluated by comparing the provisions of this new dated convention

\footnotetext{
Dr. Öğr. Üyesi, Erzincan Binali Yıldırım Üniversitesi Hukuk Fakültesi Öğretim Üyesi e-posta: hdozer24@gmail.com

ORCID ID: 0000-0002-6341-6172

DOI : :10.34246/ahbvuhfd.775464

Yayın Kuruluna Ulaştığı Tarih : 05/10/2019

Yayınlanmasının Uygun Görüldüğü Tarih: 11/06/2020
} 
to which Turkey is not a party of the Convention and the regulations introduced for fishermen in our internal legislation. The evaluation will be limited to the minimum requirements for working on fishing vessels in order not to expand the scope of our study.

Key Words: Fishery, ILO Convention 188, Maritime Labor Law, Labor Law, Seaman

\section{Giriş}

Çalışma hayatında birbirinden farklı pek çok sektörde faaliyet gösterilmektedir. Özellikle çalışma koşulları, işin yapıldığı yer gibi etkenler dikkate alındığında, her sektörün kendine mahsus ihtiyaçları bulunmaktadır. İş mevzuatımız ortak hukuk kuralları getirebilmek amacıyla genel düzenlemeler içermekte ve 4857 sayılı İş Kanunu ülkemizdeki pek çok işyerinde uygulanan yürürlükteki genel kanun olarak karşımıza çıkmaktadır. Sözü edilen kanun dışında, Basın İş Kanunu, Deniz İş Kanunu gibi kanunlar kapsamına giren kişiler bakımından kendilerine has düzenlemeler içeren özel kanunlar da bulunmaktadır. Benzer ihtiyaçlardan dolayı, Tarım İş Kanunu, Hava İş Kanunu gibi kanunların da bir an önce hazırlanıp uygulamaya konulması gerekmektedir.

Çalışmamızda, çalışma koşulları ve işin yapıldığı yer itibariyle diğer çalışma biçimlerinden farklılık arz eden balıkçılık sektöründe çalışanlar ele alınacaktır. Kavram olarak hangi çalışanların "balıkçı” olarak nitelendirildiği tespit edildikten sonra, çalışma ilişkileri bakımından balıç̧ıların hangi kanun kapsamına dahil olacakları belirlenecektir. Ülkemizdeki balıkçılık sektöründe yaygın olarak uygulanan çalışma türlerinin iş hukuku açısından değerlendirilmesi yapılarak, balıkçı kavramının iş hukuku açısından hukuki niteliği ortaya konulmaya çalışılacaktır.

Çalışmamızda ikinci olarak, (Uluslararası Çalışma Örgütü/International Labor Organization) ILO'nun yeni tarihli 188 sayılı Balıçılık İstihdam Sözleşmesi ${ }^{1}$ incelenerek, uluslararası hukukta balıkçılık sektöründe çalışanlara tanınan iş hukukuna ilişkin haklar ele alınacaktır. Henüz iç hukukumuza dahil

1 ILO’nun 2007 yılında kabul ettiği, 16.11.2017 tarihinde yürürlüğe girmiş olan Balıkç1lık İstihdam Sözleşmesi, henüz ülkemiz tarafindan onaylanmamıştır. Anılan Sözleşme, çalışmamızda bundan böyle "188 sayılı Sözleşme" olarak ifade edilecektir. 
edilmemiş olan 188 Sayılı sözleşmedeki esaslar ile balıkçılar için getirilen mevcut düzenlemeler değerlendirilerek, mevzuatımızdaki eksik yönler tespit edilmeye çalışılacaktır. Ancak 188 sayılı Sözleşme, içerdiği konular itibariyle oldukça geniş olduğundan, çalışmamızda sadece balıkçı gemilerinde çalışmak için aranan asgari koşullar konusu ile sınırlı olarak bir değerlendirme yapilacaktır.

\section{Temel Kavramlar}

\section{A. Balıkçılık Sektörü}

Balıkçıların çalışma hayatına ilişkin haklarını ortaya koyabilmek için öncelikle balıkçılık sektörünün sınırlarının ortaya konulması gerekmektedir. Sektör, genellikle avcılık ve su ürünleri yetiştiriciliği olarak anılmakta ve üst kavram olarak su ürünleri üretimi ifade edilmektedir². Burada belirtmek gerekir ki, çalışmamızda su ürünleri üretiminin tamamında çalışanlar değil, sadece balık avcılığı yapmakta olanların çalışma yaşamından kaynaklanan hak ve yükümlülükleri ele alınacaktır. Dünya genelinde kayda değer bir işgücü istihdamına sahip olan bu sektörde, Birleşmiş Milletler Gıda ve Tarım Örgütü'nün (FAO) $)^{3}$ verilerine göre, 90'l1 y1llarda 15 milyon tam zamanl1, 13 milyon yarı zamanlı kişi çalışırken, balıkçılık ve su ürünleri yetiştiriciliği üretiminde ise yaklaşık toplam 36 milyon kişi çalışmaktadır. 2000'li yıllara gelindiğinde ise, yaklaşık 27 milyon kişinin dünya genelinde yalnızca balık avında istihdam edildiği görülmektedir. Bu sektörden elde edilen üretim, FAO verilerine göre, 2017 yılı itibariyle, yaklaşık 172, milyon tona ulaşmıştır. Bu üretimin 92,5 milyon tonu (balık) avcılığından elde edilmiştir.

Dünya toplam balıkçılık üretiminin \%55'ni yakalama balıkçılığı (93,7 milyon ton), \%45'ni kültür balıkçılığ (76,6 milyon ton) oluşturmakta

\footnotetext{
EMIROĞLU, s.82-86.
}

3 Birleşmiş Milletler Gıda ve Tarım Örgütü (FAO), Birleşmiş Milletler çatısı altında, gerek gelişmiş ve gerekse gelişmekte olan ülkelerde açlikla mücadelede ve yoksulluğun önlenmesinde uluslararası düzeydeki çabaların önderliğini yürüten $\mathrm{BM}$ kuruluşudur. $\mathrm{Bu}$ görevin yanı sıra gelişmekte olan ülkelerin doğal kaynaklarını korumak suretiyle tarımsal kapasitelerini yükseltmek, ormancılık ve balıkçlık faaliyetlerini desteklemek, gıda güvenliğini temin etmek ve sürdürülebilirliğini sağlamaktır. Örgüte 194 devlet üye olup, Türkiye 1948'den bu yana üyedir, (https://www.tarimorman.gov.tr/ABDGM/Menu/66/BmGida-Ve-Tarim-Orgutu-_fao_,erişim tarihi, 27.08.2019.)

4 İstatistikî veriler için Kaynak:FAO, T.C. Tarım ve Orman Bakanlığı Su Ürünleri İstatistikleri,https://www.tarimorman.gov.tr/BSGM/Belgeler/Icerikler/Su\%20 $\% \mathrm{C} 3 \% 9 \mathrm{Cr} \% \mathrm{C} 3 \% \mathrm{BCnleri} \% 20$ Veri $\% 20 \mathrm{ve} \% 20 \mathrm{D} \% \mathrm{C} 3 \% \mathrm{~B} 6 \mathrm{k} \% \mathrm{C} 3 \% \mathrm{BC}$ manlar $\% \mathrm{C} 4 \% \mathrm{~B} 1 / \mathrm{Su}-$ $\% \mathrm{C} 3 \% 9 \mathrm{Cr} \% \mathrm{C} 3 \% \mathrm{BCnleri-} \% \mathrm{C} 4 \% \mathrm{~B} 0$ statistikleri.pdf, erişim tarihi 28.08.2019. 
ve bu üretimi gerçekleştiren ülke sıralaması ise, Çin, Endonezya, Amerika Birleşik Devletleri, Hindistan, Peru ve Rusya Federasyonu olarak karşımıza çıkmaktadır ${ }^{5}$. Türkiye 700 bin ton civarındaki toplam üretim ile listede ancak 30. sirada yer almaktadır ${ }^{6}$.

Dünya genelinde sürdürülen deniz balıkçılığını faaliyet gösterilen coğrafi alan itibariyle hukuki açıdan dört farklı başlık altında toplamak mümkündür. Bunlar; kıyı balıkçılığı (kısa mesafe balıkçılığı), sahil balıkçılığ1 (orta mesafe), uzun menzil balıkçılığı ve nihayet açık deniz balıkçılı̆̆ıdır? Dünya balıkçılığının büyük bir çoğunluğu uzun menzil ve açık deniz balıkçı1ığı iken, Türkiye'deki balıkçılığın büyük bir kısmı kıyı balıkçılığ1 -ki kıyı balıkçılığında sefer süresi gidiş geliş en çok 24 saattir- çok az bir kısmı da sahil balıkçılığıdır ${ }^{8}$. İstanbul ve Marmara, Ege, Akdeniz, Karadeniz Bölgeleri Deniz Ticaret Odasının yaptığı bir başka ayrıma göre ise, ülkemiz karasularında yapılmakta olan balıkçılık (Kıyı balıkçı̆̆ı) Artisanal Balıkçılık (Uzatma ağları, kıyı sürükleme ağları, pareketa, dalyan ve (Kıyı ötesi) Endüstriyel Balıkçılık (Gırgır-trol) olarak ikiye ayrılmaktadır9.

Türkiye açısından balıkçılık sektörü incelendiğinde, toplam su ürünleri kaynaklarımızın yüzey alanları itibariyle orman alanlarımızdan fazla, tarım alanlarımıza ise hemen hemen eşit olduğu görülmektedir. Su ürünleri üretiminin yaklaşık \%73,9'u deniz ürünleri, \%6,7'si içsu ürünleri ve \%19,5'u da yetiştiricilik ürünlerinden oluşmaktadır ${ }^{10}$. Elde edilen su ürünleri miktarı ise, 2018 y1lı verilerine göre toplam 628 bin ton olup, bunun 314 bin tonunu balıkçılık oluşturmaktadır ${ }^{11}$.

TATAR/ADALI/ÖZER, s. 515.

6 İstanbul ve Marmara, Ege, Akdeniz, Karadeniz Bölgeleri Deniz Ticaret Odası Deniz Sektörü 2017 Y1l1 Raporu, İ s t a n b u 12018 ,

s. 272, https://www.denizticaretodasi.org.tr/Media/SharedDocuments/sektorraporu/2017_ sektor_tr.pdf. erişim tarihi 26.08.2019.

7 Açık deniz balıkçılığı, 1982 tarihli BM Deniz Hukuku Sözleşmesinin 86. maddesinde tanımlanan açık deniz ifadesi gereği, bir kıyı devletinin karasuları, bitişik bölge, münhasır ekonomik bölge ve takımada suları dışında bulunan deniz alanlarında yapılan balıkçılıktır, (CIN, s.39).

8 YENIGÜ̈N, s. 190.

9 İstanbul ve Marmara, Ege, Akdeniz, Karadeniz Bölgeleri Deniz Ticaret Odası 2014 Y11 Deniz Sektörü Raporu İstanbul -2015, s. 247.

10 TATAR/ADALI/ÖZER, s 516.

11 Kaynak: FAO, T.C. Tarım Ve Orman Bakanlığı Su Ürünleri İstatistikleri, https://www. tarimorman.gov.tr/BSGM/Belgeler/Icerikler/Su\%20\%C3\%9Cr\%C3\%BCnleri $\% 20$ Veri\%20ve\%20D\%C3\%B6k\%C3\%BCmanlar\%C4\%B1/Su-\%C3\%9Cr\%C3\%BCnleri-

70 Ankara Hacı Bayram Veli Üniversitesi Hukuk Fakültesi Dergisi C. XXIV, Y. 2020, Sa. 3 
Türkiye'de balıkçılık faaliyetleri 1970'li yıllara kadar çoğunlukla zanaat balıkçılığı ya da küçük ölçekli gündelik balıkçılık olarak yürütülmekteydi. 1971 yılında Su Ürünleri Kanunu'nun ${ }^{12}$ yürürlüğe girmesiyle birlikte teknolojik gelişmelerin de katkısıyla balıkçılık önemli bir gelişme kaydetmiştir ${ }^{13}$. Sektördeki gelişim sürecinin ardından Türkiye'de su ürünleri üretimi, hem deniz hem de iç sularda yapılan avcılık ve yetiştiricilik (kültür balıkçılığı) üretimi olarak iki biçimde gerçekleşmektedir. Deniz avcılığı, geleneksel (küçük) balıkçılık ve endüstriyel (ticari) balıkçılık olmak üzere iki farklı tipte yapılmaktadır. Geleneksel balıkçılık çoğunlukla 12 metreden küçük teknelerle yapılan kıyı balıkçılığı olarak tanımlanırken, endüstriyel balıkçılık faaliyetleri ise 12 metrenin üzerinde girgır ve trol denilen balıkçı tekneleriyle gerçekleşen kıyı ötesi balıkçılığıdır ${ }^{14}$.

\section{B. Balıkçılık ve İlgili Diğer Kavramlar}

\section{Balıkçılık}

Balıkçılık kavramının Türk Dil Kurumu sözlüğünde yapılan tanımı denizlerde, göllerde ve akarsularda balıkların ve diğer deniz canlılarının çeşitli yöntemlerle avlanması olarak karşımıza çıkmaktadır. Balıkların yanısıra midye, karides, 1stakoz, pavurya, istiridye hatta balina gibi deniz memelilerinin avlanması da balıkçılık kapsamına girer. Gölet, havuz ya da denizlerdeki suni tesislerde balık ve diğer deniz hayvanlarının üretilmesi de balıkçılığın bir parçasıdır ${ }^{15}$.

188 sayılı ILO Sözleşmesi'nde ise, ticari balıkçılığın tanımı şu şekilde verilmiştir; "geçimlik balıkçılık ve rekreasyonel(hobi) balıkçılık hariç, nehir, göl veya kanallardaki balıkçılık faaliyetleri dahil tüm balıkçılık faaliyetleridir." (m. 1/a). Ticari balıkçılığa ilişkin bir diğer tanım ise, "balık ve diğer deniz ürünlerini pazarlama amaciyla okyanuslardan, denizlerden, nehirlerden ve göllerden yakalama faaliyeti” biçiminde yapılmıştır ${ }^{16}$.

\%C4\%B0statistikleri.pdf, erişim tarihi 28.08.2019.

121380 sayılı Su Ürünleri Kanunu, RG. 04.04.1971, 13799.

13 TANTOĞLU, s. 3.

14 ULUKAN, s. 117-118. Yazarın belirttiğine göre, çalışan sayısı küçük gırgır teknelerinde 10-15, büyük teknelerde ise 30-40 kişiye ulaşmaktadır.

15 https://tr.wikipedia.org/wiki/Bal\%C4\%B1k\%C3\%A7\%C4\%B11\%C4\%B1k, erişim tarihi 26.08.2019.

16 DOĞANYILMAZ ÖZBILLGIN/TOK, s. 139. 
188 sayılı Sözleşme'nin 2/a maddesinde kapsama ilişkin yapılan belirlemede bu sözleşmenin aksi belirtilmedikçe ticari balıkçılar ve balıkçı teknelerine uygulanacağı ifade edilmiştir. $\mathrm{Bu}$ nedenle tanım olarak da sadece ticari balıkçılık üzerinde durulmuştur. Tanımda yer alan geçimlik balıkçılık ile rekreasyonel balıkçılık özü itibariyle bir bağımlı çalışma olgusu içermediğinden, inceleme konumuz dışında kalmaktadır.

Rekreasyonel (hobi) balıkçılığın ilgili tebliğde yapılan tanımı şu şekildedir; spor yapmak ve hoş vakit geçirmek amacıyla yapılan balıkçılık faaliyetidir ${ }^{17}$. Benzer bir biçimde, 2015/523 AB Direktifinde ${ }^{18}$, "rekreasyon, turizm veya spor gibi deniz canlıları gibi su kaynaklarını kullanan ticari olmayan balıkçılık faaliyetleri" olarak tanımlanmıştır. Geçimlik balıkçılık ise, hobi amaçlı olarak yapılan balıkçılık faaliyetinden farklı olarak, balıkçılık yapan kişinin ailesi ve yakınlarının beslenmesinde kullanılmak üzere yapılan balıkçılıktır ${ }^{19}$. S1k rastlanılan ve zanaatkarlık olarak adlandırılan bu balıkçılık faaliyetinde küçük ölçekli balık satışları da yapılmaktadır ${ }^{20}$. Söz konusu balıkçılıkta aslolan avlanan balığın satılması değil, ailenin kullanımı için tüketilmesidir ${ }^{21}$.

\section{Balıkçı}

Çalışmamızda "balıkçı" olarak kullandığımız kavram, uluslararası metinlerde değişik biçimlerde ifade edilmektedir ${ }^{22} .188$ say1lı Sözleşme'nin 1/e maddesinde ise balıkçı şu şekilde tanımlanmıştır; "Balıkçı gemisinde herhangi bir konumda çalışan ve ücretli ya da tutulan balık üzerinden pay alma biçiminde gelir elde eden, kılavuz kaptan, balıkçılık gözlemcisi ve limanda görev yapan diğer kamu görevlileri dışında kalan bu mesleği icra eden kişiler"dir.

17 2/2 Numaralı Amatör (Sportif) Amaçlı Su Ürünleri Avcıllğını Düzenleyen Tebliğ Yayımlandığı R.Gazete: 21.08.2008-26974.

18 Counc1l Regulation (EU) 2015/523 Of 25 March 2015.

19 Amatör, sportif balıkçılık tanımları için bkz. 2 Numaralı Amatör (Sportif) Amaçlı Su Ürünleri Avcıllığını Düzenleyen Tebliğ (Tebliğ No: 2008/49).

20 Subsistence Fishing, World Fisheries Trust $2008 \quad$ http://www. worldfish.org/GCI/gci_assets_moz/Fact\%20Card\%20-\%20Subsistence\%20Fishing.pdf, erişim tarihi, 26.08.2019.

21 ILO Working Paper No. 315, "The flexibility Clauses of the Work in Fishing Convention, 2007 (No. 188)", s. 12.

22 Bu kavramla ilgili olarak, ILO "fisherman" ve "sea fisherman" kavramlarını kullanırken, FAO, "fisher", IMO (Uluslararası Denizcilik Örgütü), "fishing vessel personnel" kavramını tercih etmektedir, (Fishing Sector Report, s. 3) 
Ancak bu tanım, balıkçı gemisinde doğrudan balıkçılık faaliyetiyle uğraşmayıp da, örneğin navigasyonla uğraşan bilim adamı niteliğinde personelin kapsam dışında kalmasına yol açmaktadır ${ }^{23}$. Sözleşmeye henüz taraf olmadığımızdan, bizim hukukumuzda balıkçı kavramını balıkçı gemisinde faaliyet gösteren tüm çalışanlar olarak anlamak mümkündür ${ }^{24}$.

2006 tarihli Denizcilik Çalışma Sözleşmesi'nin 2/1-f maddesinde ise, benzer bir kavram olarak denizci (seafarer) tanımı şu şekilde yapılmıştır; denizci, bu Sözleşmenin uygulandiğı bir gemide herhangi bir konumda çalışan herhangi bir kişidir."

Belirtmek gerekir ki, her ne kadar denizci ve balıkçı kavramları benzer kavramlar olsalar da, balıkçılık faaliyetinin 2006 Deniz Çalışma Sözleşmesi'nin kapsamında olmadığı hatırlandığında, inceleme konumuz açısından denizci kavramının balıkçı kavramını da içine alan çok geniş bir anlama sahip olduğu söylenebilir.

Deniz İş Kanunu m. 2/B'de, "Bir hizmet akdine dayanarak gemide çalışan kaptan, zabit ve tayfalarla diğer kimselere "gemi adamı" denir." ifadelerine yer verilmiştir ${ }^{25}$. Tanım, yukarıda balıkçı olarak tanımladığımız kişilerin de deniz iş hukuku açısından gemi adamı sayılacağı sonucunu ortaya çıkarmaktadır ${ }^{26}$.

Ticari amaçlı olarak yapılan balıkçılık faaliyetini gerçekleştiren balıkçı kavramı, Balıkçı Barınakları Yönetmeliği'nin ${ }^{27}$ 3. maddesinde, “Ticari amaçla deniz ve iç sularda su ürünleri istihsal eden kaptan, balıkçı reisi, balıkçı ve tayfa gibi gerçek kişiler ile tüzel kişileri, bunların ortak ve çalışanları ile su

23 CARBALLO Pİ NEIRO, s. 25.

24 Balıkçı Gemilerinde Yapılan Çalışmalarda Sağlık ve Güvenlik Önlemleri Hakkında Yönetmelik'in 4/1-a maddesi 1şığında.

25 Benzer bir şekilde, RG., 30328 say1 ve 10.02.2018 tarihli Gemiadamları ve Kılavuz Kaptanlar Yönetmeliği'nin 3/s maddesinde de, "Geminin kaptanı, zabitleri, yardımc1 zabitleri, stajyerleri, tayfaları ve yardımcı hizmet personeli" olarak tanımlama yapılmıştır.

26 Gemiadamları ve Kılavuz Kaptanlar Yönetmeliği’nde ayrıca gemi adamları yeterlilik dereceleri bakımından sınıflara ayrılmıştır. $\mathrm{Bu}$ sınıflamada balıkçı sınıfı gemiadamları da yer almaktadır. Balıkçı sınıfı gemiadamlarının yeterlik isim ve dereceleri ise, "balıkçı gemisi güverte tayfası, "balıkçı gemisi kaptanı", "açık deniz balıkçı gemisi kaptanı” olarak belirlenmiştir. (m.4/5). Ancak aşağıda da değinileceği üzere, Gemi Adamlarının İkamet Yerleri, Sağglı ve İaşelerine Dair Yönetmelik'de balık avı ve benzeri işlerde faaliyet gösteren gemilerde çalışan gemi adamlarının bu yönetmelik kapsamında olmayacağı belirtilmiştir.

27 RG., 22846, 13.12.1996. 
ürünleri yetiştiricileri" olarak tanımlanmıştır. Bu konuda bir başka tanım da doğrudan balıkçı kavramı olmasa da "balıkçı gemilerinde çalışanlar" olarak yapılmıştır. Balıkçı Gemilerinde Yapılan Çalışmalarda Sağllk ve Güvenlik Önlemleri Hakkında Yönetmelik ${ }^{28}$ in 4/1-a maddesinde yer verilen tanım ise şu şekilde yapılmaktadır; "Limanda görev yapan personel ve kılavuz kaptanlar hariç, yardımcı olarak çalışanlar ve stajyerler dahil gemide çalışan kişi”".

\section{Balıkçı Gemisi}

Balıkçı gemisinin ${ }^{29}$ tanımı, Balıkçı Gemilerinde Yapılan Çalışmalarda Sağlık ve Güvenlik Önlemleri Hakkında Yönetmelik'in 4/1-a maddesinde şu şekilde yapılmıştır; "Ticari amaçla denizden balık veya diğer canlıları avlamakta veya avlayıp işlemekte kullanılan, Türk Bayrağ taşlyan gemi”. Söz konusu yönetmelik, 23/11/1993 tarihli ve 93/103/EC say1lı Avrupa Birliği Direktifi'ne ${ }^{30}$ paralel olarak hazırlanmıştır. Anılan Direktifte yapılan balıkçı teknesi tanımı ise, "Denizden ticari maksatl balık veya diğer yaşam kaynaklarını çıkaran ve işleyen veya sadece tutan, Üye bir Devletin bayrağını taşıyan veyahut Üye bir Devletin yetki alanı altında kayıtlı herhangi bir deniz taşıtı" olarak yapılmıştır. Balıkçı gemisini tanımlayan bir diğer Yönetmelik ise, Balıkçı Gemilerinin Emniyeti Hakkında Yönetmelik ${ }^{31}$ olup, benzer tanım şu şekilde yapılmıștır; "Ticari olarak balık veya başka deniz canlıları yakalamak için teçhiz edilmiş olan veya kullanılan herhangi bir gemi" dir. Konuya deniz iş hukuku açısından bakıldığında, gemi kavramının açık bir tanımına Deniz İş Kanunu'nda yer verilmediği ancak Türk Ticaret Kanunu'nda bir tanımın bulunduğu görülmektedir ${ }^{32}$.

$28 \quad$ RG., 28741, 20.08.2013.

29 Ülkemizde ticari avcılık yapan balıkçı gemisi sayısı 17165'tir. Ancak bunların sadece 1491 tanesi endüstriyel balıkçı gemisidir. Balıkçı filosunda etkin avcılık yapan grup, gırgır ve trol gemileridir. Toplam üretimin \%90'ı bu grup tarafından karşılanmakta olup bu gemilerin boyları 12 metreden başlayarak 50 metreye kadar ulaşabilmektedir, (TANTOĞLU, s. 5).

30 23.11.1993, Official Journal, L 307/1. Balıkçı Teknelerinde Çalışma Konusundaki Asgari Emniyet ve Sağllk Gerekliliklerine İlişkin Konsey Direktifi.

31 RG. 26089, 23.02.2006.

32 TTK.m.931'e göre, "Tahsis edildiği amaç, suda hareket etmesini gerektiren, yüzme özelliği bulunan ve pek küçük olmayan her araç, kendiliğinden hareket etmesi imkânı bulunmasa da, bu Kanun bakımından "gemi" sayllır. (2) Suda ekonomik menfaat sağlama amacına tahsis edilen veya fiilen böyle bir amaç için kullanılan her gemi, kimin tarafindan ve kimin adına veya hesabina kullanılırsa kullanılsın "ticaret gemisi" sayılır." 
188 sayılı Sözleşme m. 1/g'de yapılan balıkçı gemisi tanımı ise, "ticari balıkçılık amacıyla kullanılmakta olan veya kullanılma biçimine bakılmaksızın, mülkiyet biçiminden bağımsız olarak, herhangi bir nitelikte olan herhangi bir gemi veya tekne" biçiminde yapılmıştır.

Bilindiği üzere, deniz iş hukukunda gemilerin büyüklüğüne göre çeşitli sınıflandırmalar yapılmaktadır. Örneğin Deniz İş Kanunu kapsamına 1. maddesi gereği "yüz ve daha yüksek grostonilatoluk gemiler" girmektedir. Bu durumda daha küçük balıkçı teknelerinin kanun kapsamı dışında kalacağı sonucu ortaya çıkmaktadır ${ }^{33}$. Böylece ileride inceleneceği üzere özellikle beşten az gemi adamının çalıştığı ve yüz grostonilatodan küçük balıkçı teknelerinde çalışanların hangi kanun kapsamına dahil olacakları sorusu akla gelmektedir. Oysa 188 sayılı Sözleşmede gemilere yönelik bir büyüklük sınırlaması bulunmamakta, büyük küçük tüm balıkçı gemileri amatör ve sportif amaçlı balıkçılık yapmadıkları müddetçe sözleşme kapsamına dahil olabilmektedir ${ }^{34}$. Bu husus, Sözleşme m. 2/3'de, taraf devletlerin bu sözleşme kapsamındaki korumadan 24 metreden daha küçük balıkçı gemilerinde çalışanları da yararlandırmaya karar verebileceği yönünde ifade edilmektedir.

\section{Balıkçılıkla İlgili Uluslararası ve Ulusal Mevzuat}

\section{A. Uluslararası Denizcilik Örgütü Sözleşmeleri}

IMO (Uluslararası Denizcilik Örgütü/International Maritime Organization), Birleşmiş Milletler, deniz taşımacılığının emniyet ve güvenliğinden ve gemilerin deniz ve atmosfer kirliliğinin önlenmesinden

33 DİK.m.1/2 hükmü ile birlikte değerlendirildiğinde, aynı işverene ait gemilerin grostonilatoları toplamı yüz veya daha fazla olduğu veyahut işverenin çalıştırdığ daha fazla bulunduğu takdirde de deniz iş kanunu uygulama alanı bulacaktır. Ülkemizdeki balıkçı gemileri incelendiğinde, genellikle bir gemide çalışanlar Kocareis, makinist, aşçı, palacı ve kamarot çoğu zaman bir kişiden oluşurken teknelerin büyüklüğüne göre ortalama olarak botçu 1-3 kişi, ırgatç1 1-3 kişi, hamlacı ve mantarc1 2-3 kişi, torcular 8-15 kişiden oluşmaktadır. Bu kişiler aynı zamanda balık tekneye alındığında kasalama işini de üstlenmektedirler, (ULUKAN, s. 130). Sonuç olarak küçük çaplı balıkçı teknelerinde dahi 5 personelden fazla kişi görev yaptı̆̆ından, ileride de değinileceği gibi pek çok balıkçı Deniz İş Kanunu kapsamına dahil olmaktadır.

34 ILO verilerine göre, balıkçı gemilerinde çalışanların \%90'1 24 metrenin altında olan gemilerde çalışmaktadır, bkz. (Decent Working Conditions Safety and Social ProtectionWork in Fishind Convention No:188, Recommendation 199 Booklet 2007, s. 3,

https://www.ilo.org/sector/Resources/publications/WCMS_161209/lang--en/index.htm, erişim tarihi 29.08.2019). 
sorumlu olan uzmanlaşmış bir kuruluştur ${ }^{35}$. Bazı balıkçı gemileri aynı zamanda deniz taşımacılığ da yapmakta olduklarından, IMO Sözleşmeleri balıkçılık sektörünü de ilgilendirebilmektedir.

IMO Sözleşmeleri içinde anılması gereken ilk kaynak 1977 tarihli Torremolinos Protokolü'dür. Balıkçı Teknelerinin Emniyeti için Torremolinos Uluslararası Sözleşmesine ilişkin Torremolinos Protokolünün 2 Nisan 1993 tarihinde kabul edilmiştir. Bu protokolde 24 metre ve üzeri balıkçı gemileri için tasarım, yapım ve ekipmanlarla ilgili kurallar ve prensipler bulunmaktadır. Türkiye bu protokolü esas alarak, "Balıkçı Gemilerinin Emniyeti Hakkında Yönetmelik"i kabul etmiştir ${ }^{36}$.

Balıkçı gemilerinin güvenliğini arttırmak için IMO'nun yıllardır yaptığ1 çalışmalar, 2012 tarihli Cape Town Sözleşmesi'ne de temel oluşturmuştur. Sözleşmede açık denizlerde seyreden büyük balıkçı gemilerinde güvenliği sağlamak için gerekli tedbirlere yer verilmekte ve stabilite, gemi inşa, mürettebatı koruyucu önlemler vb. konular ele alınmaktadır. Bu sözleşmeyle, özellikle büyük balıkçı filosuna sahip ülkelerin 1993 tarihli Torremolinos Protokolü'nü uygularken karşılaştıkları sorunların ortadan kaldırmak ve balıkçı gemilerinin güvenliğini sağlamaya yönelik uluslararası standartlar belirlenmesi amaçlanmaktadır ${ }^{37}$.

Bunların dışında, ülkemizin de taraf olduğu üç temel IMO Sözleşmesi $\left(\mathrm{MARPOL}^{38}, \mathrm{SOLAS}^{39}, \mathrm{STCW}^{40}\right.$ ) de bulunmaktadır. Ancak bu sözleşmeler doğrudan balıkçıların çalışma esaslarına ilişkin düzenlemeler değildir.

35 http://www.imo.org/en/About/Pages/Default.aspx, erişim tarihi, 19.09.2019. 1958 yılında IMO Sözleşmesi yürürlüğe girmiş olup, aynı yıl Türkiye de IMO'ya üye olmuştur. Üyeliğimiz halen devam etmektedir.

36 DOĞANYILMAZ ÖZBİLGIN/TOK, s. 140.

37 IMO'dan Haberler İMEAK Deniz Ticaret Odası Eylül (2017) Bülteni, http://www.vda.org. tr/upload/duyuru/Eyl\%C3\%BCl\%20b\%C3\%BClten_2017.pdf, erişim tarihi 29.08.2019.

381978 Protokolü ile Değişik 1973 Tarihli Denizlerin Gemiler Tarafından Kirletilmesinin Önlenmesine Ait Uluslararası Sözleşme.

391974 Denizde Can Emniyeti Uluslararası Sözleşmesi.

401995 Balıkçı Gemileri Personelinin Eğitim, Belgelendirme ve Vardiya Standartları Hakkında Uluslararası Sözleşme.

76 Ankara Hacı Bayram Veli Üniversitesi Hukuk Fakültesi Dergisi C. XXIV, Y. 2020, Sa. 3 


\section{B. Uluslararası Çalışma Örgütü Sözleşmeleri}

\section{2006 Denizcilik Çalışma Sözleşmesi (Maritime Labour Convention-MLC)}

"Denizcilik Çalışma Sözleşmesi 2006", ILO Genel Konferansınca 7 Şubat 2006 tarihinde kabul edilip, 20.08.2012'de yürürlüğe girmiştirit ${ }^{41}$ Ülkemiz açısından da "Denizcilik Çalışma Sözleşmesinin Onaylanmasının Uygun Bulunduğuna Dair Kanun” 25.03.2017 tarihi itibariyle yürürlüğe girmiştir ${ }^{42}$. Sözleşme, gemiadamları bakımından denizcilikle ilgili kapsamlı çalışma, ilke ve haklar getirmekte, yaşam ve çalışma koşullarını iyileştirmekte, kişisel haklar ve yasal çözüm yolları hususunda daha iyi bilgilendirilmelerini ve her düzeyde gelişmiş bir sosyal diyalog tesis edilmesini sağlamaktadır ${ }^{43}$. Sözleşmenin bir diğer önemli özelliği ise, 1920 ile 1996 yılları arasında denizcilik sektöründe çalışmayla ilgili kabul edilmiş 37 ILO sözleşmesini yürürlükten kaldırmış olmasıdır ${ }^{44}$.

Gemiadamlarına yasal koruma sağlamayı hedefleyen bu temel sözleşme, kargo ve yolcu gemilerinde çalışan gemiadamlarıyla balıkçı gemilerinde çalışanlar arasında karşılaştıkları çalışma koşulları açısından farklılık olduğu için, balıkçı gemilerinde çalışan gemiadamlarını kapsam dışında tutmuş ve bunun yerine ILO tarafından ticari balıkçılık faaliyetinde çalışanlara yönelik ayrı bir sözleşme olan 188 sayılı Balıkçılık Çalışma sözleşmesi düzenlenmiştir.

\section{Diğer ILO Sözleşmeleri}

ILO'nun balıkçılık sektörüne yönelik olarak kabul ettiği ilk metin, 1920 yılında onaylanmıştır. Daha sonrakiler ise, 1959 ve 1966 yıllarında kabul edilmiştir ${ }^{45}$. Yukarıda da belirtildiği gibi 2006 Denizcilik Çalışma

41 Denizcilik Çalışma Sözleşmesi, 2006'nın yürürlüğe girmesi için gerekli olan dünya toplam gemi tonajının \%33'üne sahip en az 30 ILO üyesi Devlet tarafindan onaylanması koşulu, 20.08.2012 tarihinde karşılanmış ve Sözleşme bu tarih itibarıyla 30 ülke için yürürlüğe girmiştir.

42 RG. 30018, 25.03.2017.

43 Denizcilik Çalışma Sözleşmesinin Onaylanmasının Uygun Bulunduğuna Dair Kanun genel Gerekçesi, s. 23. Ayrıca bkz. ALGANTÜRK LIGHT, s. 269-275.

44 SÜZEL, s. 181.

45 ILO Work in Fishing Convention and Recommendation, 2007 Action Plan 2011-2016, International Labour Office Genova, 2011, s. 2,

https://www.ilo.org/wcmsp5/groups/public/---ed_dialogue/---sector/documents/ publication/wcms_161220, erişim tarihi, 04.10.2019. 
Sözleşmesi’nin kabulünün ardından denizcilik sektörüne yönelik 37 sözleşme yürürlükten kalkmıştır. Doğrudan balıkçılık alanına ilişkin olarak hazırlanan diğer ILO sözleşmelerinin bir kısmı da 188 sayılı Sözleşmenin yürürlüğe girmesinin ardından sözleşmenin 46. maddesi uyarınca yürürlükten kalkmıştır. Bunlar; 112 sayılı Balıkçılıkta Asgari Yaşa ilişkin ILO Sözleşmesii" ${ }^{46}, 113$ sayılı Balıkçılar İçin Tıbbi Muayeneye ilişkin ILO Sözleşmesi ${ }^{47}$, 114 sayılı Balıkçıların Sözleşme Hükümlerine İlişkin ILO Sözleşmesi, ${ }^{48} 126$ sayılı Balıkçı Gemilerinde Mürettebatın Konaklamasına İlişkin ILO Sözleşmesi ${ }^{49}$ dir. Bir kısmı ise hala yürürlüktedir. Bunlardan biri 166 sayılı Gemiadamlarının Ülkelerine Geri Gönderilmesine İlişkin Sözleşme ${ }^{50}$ dir. Bir diğeri, 125 sayıl1 Balıkçıların Yetkinlik Sertifikaları Sözleşmesi'dir ${ }^{51}$.

\section{188 Sayılı Balıkçılık Çalışma ILO Sözleşmesi ve 199 sayılı ILO Tavsiye Kararı}

ILO tarafindan 2007 y1lında kabul edilen bu sözleşme, 16.11.2017 tarihinde yürürlüğe girmiştir ${ }^{52}$. Balıkçılık, pek çok hukuk sisteminde genellikle mevzuat kapsamı dışında tutulan bir çalı̧̧ma türü olduğundan, bu Sözleşme işverenler için temel bir yükümlülük çerçevesi çizmekte ve üye devletler için ise asgari standartları ulusal mevzuata dahil etme konusunda yükümlülükler içermektedir.

Sözleşme, ticari balıkçı gemilerinde çalışanlar için iyi çalışma koşullarında çalışmalarını sağlamak için asgari standartlar getirmeyi amaçlamaktadır. Bu bağlamda, iş sözleşmesi şartları, konaklama ve yemek; iş

461959 tarihli bu sözleşme 07.11.1961'de yürürlüğe girmiştir. Türkiye bu sözleşmeye taraf değildir.

471959 tarihli bu sözleşme 07.11.1961'de yürürlüğe girmiştir. Türkiye bu sözleşmeye taraf değildir.

481959 tarihli bu sözleşme 07.11.1961'de yürürlüğe girmiştir. Türkiye bu sözleşmeye taraf değildir.

491966 tarihli bu sözleşme 06.011.1968'de yürürlüğe girmiştir. Türkiye bu sözleşmeye taraf değildir.

50 ILO kabul tarihi 24.09.1987, Türkiye tarafından onaylanan sözleşmenin yürürlüğe giriş tarihi, 2003 y1lıdır. RG. 25317, 15.12.2003. Anılan sözleşmeni 1/2. maddesine göre, taraf devletlere yetkili makamlarla görüş alışverişi yaptıktan sonra sözleşme hükümlerini ticari balıkçı gemilerine de uygulama kararı verme yetkisi tanınmıştır.

511966 tarihli bu sözleşme 15.07 .1969 'da yürürlüğe girmiştir. Türkiye bu sözleşmeye taraf değildir.

52 Sözleşmenin, sekizi kıyı ülkesi olmak üzere toplam on üye devletin onaylaması sonucu yürürlüğe gireceğine ilişkin hükmü 2017 yılı itibariyle gerçekleşmiştir. 
sağlığ 1 ve güvenliği, tıbbi bakım ve sosyal güvenlik konularında düzenlemeler içermektedir. Temel olarak ulusal bayrağı taşıyan gemilerde uygulama alanı bulacak olan sözleşme, istisnai olarak yabancı bayraklı balıkçı gemileri için de liman devletinin denetimi esasını kabul etmektedir ${ }^{53}$.

Türkiye balıkçılık sektörüyle ilgili diğer sözleşmelere taraf olmadığı gibi bu sözleşmeyi de onaylamamıştır ${ }^{54}$. Sözleşme on dört ülke tarafından onaylanmış olup, on ikisinde yürürlüğe girmiş̧iir ${ }^{55}$.

ILO, 188 sayılı Sözleşmeyi desteklemek amacıyla 199 sayılı Balıkçılıkta Çalışma ILO Tavsiye Kararını kabul etmiştis ${ }^{56}$.

\section{Avrupa Birliği Müktesebatı}

$\mathrm{AB}$ direktiflerinde de balıkçılık sektöründe çalışmaya yönelik pek çok düzenlemeye yer verildiği görülmektedir. Bunların önemli bir kısmı, iş sağlığı ve güvenliği konularını düzenlemektedir. İlk olarak anılması gereken Direktif, 93/103/EC sayılı Balıkçı Teknelerinde Çalışma Konusundaki Asgari Emniyet ve Sağlı Gerekliliklerine İlişkin Konsey Direktifi' dir $^{57}$ ve balıķı gemilerinde çalışma ortamındaki asgari güvenlik ve sağlık gerekliliklerini ortaya koymaktadır. 2013 tarihli "Balıkçı Gemilerinde Yapılan Çalışmalarda Sağlık ve Güvenlik Önlemleri Hakkında Yönetmelik" bu direktif ışığında hazırlanmıştı1 ${ }^{58}$.

53 Work in Fishing Convention and Recommendation, 2007 Action Plan 2011-2016, International Labour Office Geneva, 2011, s. 3.

54 Gerekçe olarak ise, ILO Genel kurulu oturumunda yapılan açıklamada, 188 sayılı Sözleşmenin az sayıda ülke tarafından onaylanmış olması ve balıkçılık sektöründe çalışan tüm grupları kapsamadığı için daha esnek bir sözleşmeye ihtiyaç olduğu ifade edilmiştir (International Labour Conference Provisional Record 12 Ninety-sixth Session, Geneva, 2007 Fourth item on the agenda: Work in the fishing sector (single discussion) Report of the Committee on the Fishing Sector, s. 12/7.)

55 Angora, Arjantin, Bosna Hersek, Kongo, Estonya, Fransa, Litvanya, Fas, Namibya, Norveç, Senegal, Güney Afrika'da yürürlüğe girmiştir. Tayland ve Birleşik Krallık'ta ise 2020 y1lı itibariyle yürürlüğe girecektir (Bkz. https://www.ilo.org/dyn/normlex/en/f?p=1000:11300:0 ::NO:11300:P11300_INSTRUMENT_ID:312333, erişim tarihi 03.09.2019).

56199 sayılı Tavsiye kararında, balıkçı gemilerinde çalışma koşulları, hizmet koşulları, konaklama, tıbbi bakım, iş sağlığı ve güvenliği, sosyal güvenlik gibi temel konularda 188 sayılı Sözleşmeyi açıklayıcı düzenlemelere yer verilmiştir.

57 23.11.1993, Official Journal, L 307/1. 23 Kasım 1993 tarihli 93/103/EC Sayılı Balıç̧ı Teknelerinde Çalışma Konusundaki Asgari Emniyet ve Sağlık Gerekliliklerine İlişkin Konsey Direktifi (89/391/EEC Sayılı Direktifin 16 (1) Maddesinin Kapsamı Dahilindeki 13. Bireysel Direktif), Direktif metni için bkz., http://denizmevzuat.udhb.gov.tr/Turkce/ ABdirektifleri.aspx?Baslik=3, erişim tarihi 05.09.2019.

58 RG., 28741, 20.08.2013. 
Ayrıca, 2003 tarihli Çalışma Sürelerine ilişkin 2003/88 EC sayılı Direktif' in 21. maddesinde balıkçı teknelerinde çalışanların çalışma sürelerine yönelik özel düzenlemeler bulunmaktadır ${ }^{59}$. Ayrıca Gemilerde Tıbbı Tedaviye Yönelik 92/29 EC sayılı Direktif ${ }^{60}$, 97/70 EC sayılı 24 Metre Boyunda ve Daha Büyük Balıkçı Tekneleri İçin Uyumlu Bir Emniyet Yönetimi Sağlanması Hakkında Direktif'ler ${ }^{61}$ kabul edilmiştir.

\section{Balıkçılığa İliş̧kin Ulusal Mevzuat}

\section{Balıkçılık Faaliyetine Uygulanacak Kanunun Belirlenmesi}

$\mathrm{Bu}$ başlık altında balıkçı gemisinde çalışanların, çalışma ilişkilerinin ulusal mevzuatımızda nasıl düzenlendiği incelenecektir. Balıkçıların, 4857 sayılı İş Kanunu, 854 sayılı Deniz İş Kanunu ve nihayet 6098 sayılı Türk Borçlar Kanunları'ndan hangisine tabi olacakları önem arz etmektedir. Öncelikle çalışma ilişkilerinde temel kanun niteliğinde olan İş Kanunu'ndaki hükümleri incelemek gerekmektedir. Kanun'un 1. maddesinin 2. fikrasında, "Bu Kanun, 4. maddedeki istisnalar dışında kalan bütün işyerlerine, bu işyerlerinin işverenleri ile işveren vekillerine ve iş̧̧ilerine faaliyet konularına bakılmaksızın uygulanır." hükmü yer almaktadır. Anılan 4. maddedeki istisnalara bakıldığında ise, deniz taşıma işlerinin kanun kapsamı dışında tutulduğu görülmektedir (f. 1). Balıkçılık işi deniz taşıma işlerinden sayılmadığından, bu istisnaya girmediği açıtır. İstisnaları düzenleyen maddenin devamında, " 50 'den az işçi çalıştırılan (50 dahil) tarım ve orman işlerinin yapıldığg işyerlerinde veya işletmelerinde" İş Kanunu'nun uygulanmayacağ 1 ifade edilmiştir. Tarım işlerinin yapıldığı yerler kavramına açıklık getirmek gerekmektedir. İş Kanunu m. 111'de tarımdan sayılan işler belirlenmiş olup, (d) bendinde, "854 sayıl Deniz İş Kanunu'nun hükümleri saklı kalmak kaydlyla, kara ve su avcılı̆̆ ve üreticiliği ile bu yoldan elde edilen ürünlerin saklanması ve taşınması" işleri tarım işi olarak kabul edilmiştir. Benzer düzenleme, Sanayi, Ticaret, Tarım ve Orman İşlerinden Sayılan Ișlere İlişkin Yönetmelik ${ }^{62}$ Ek-I C/4'de; " 20/4/1967 tarihli ve 854 sayll Deniz Işs Kanunu hükümleri saklı kalmak kaydıyla, kara ve su ürünleri avcllı̆ğ,

\footnotetext{
59 Official Journal, L 299 , 18/11/2003

${ }^{60}$ Official Journal L 113 , 30/04/1992. Gerekliliklerine Gemilerde İyileştirilmiş Tibbi Tedaviler İçin Asgari Emniyet ve Sağlık İlişkin 31 Mart 1992 Tarihli 92/29/EEC Sayılı Konsey Direktifi.

61 Official Journal C 292, 4.10.1996.

62 RG. 26986, 03.09.2008.
}

80 Ankara Hacı Bayram Veli Üniversitesi Hukuk Fakültesi Dergisi C. XXIV, Y. 2020, Sa. 3 
yetiştiriciliği ve üreticiliği ile bu yoldan elde edilen ürünlerin saklanması ve taşınması işleri. ${ }^{63}$ " şekilde yapılmıştır. İfade edilen "su ürünleri avcılığı", "su ürünleri üreticiliği" ve "bu ürünlerin saklanması ve taşınması" işlerinin Deniz İş Kanunu kapsamına dahil olmadığ 1 durumlarda tarım işi sayılacağ 1 , tarım işlerinde de elliden fazla işçinin çalıştığı işyerinin İş Kanunu kapsamına girdiği sonucu ortaya çıkmaktadır ${ }^{64}$. Bu durumda, İş Kanunu'nda düzenlenen tarım işi kapsamına giren elliden fazla kişinin çalıştığ balıkçılık faaliyetinin yürütüldüğü yerler Deniz İş Kanunu kapsamında olmamak koşuluyla İş Kanunu kapsamında sayılacaktır. Örneğin, sünger üreticiliğ ${ }^{65}$ faaliyetinde çalışanlar İş Kanunu kapsamındadır ${ }^{66}$. Dalyancılık faaliyetiyle ilgili olarak ise farklı görüşler bulunmaktadır ${ }^{67}$. İlk görüş, denizde yapılan bu deniz ürünleri üreticiliği niteliğindeki işin İş Kanunu kapsamında olduğunu savunmaktadır ${ }^{68}$. Aynı yönde karar veren Danıştay da, su ürünleri üreticiliği niteliğinde olan bu işin tarım işi sayılmayacağını ve bu nedenle İş Kanunu kapsamında olduğunu kabul etmiştir ${ }^{69}$. Ancak bir başka görüş ise, yasal değişikliğin ardından, tarım

63 Bu yönetmelik yürürlüğe girmeden önce verilen eski tarihli bir Yargıtay kararında, salt balık avlama işinin yapıldığı işin tarım işi sayılamayacağına karar vermiştir. Y.10.HD. 02.11.1978, 446/7803, aynı yönde olan bir başka kararda tarım işinde üretmek ve yetiştirme unsurları olduğundan açık denizde balık avlamak tarım işi sayılmamıştır, YHGK. 11.10.1972, 9-783/827, NARMANLIOĞLU, s. 83.

64 Dikkat edilmesi gereken bir başka düzenleme ise, 5510 sayılı Sosyal Sigortalar ve Genel Sağlık Sigortası Kanunu'nun 8/1-a hükmüdür. Anılan bentte, "inşaat, balıkçılık ve tarım işyerinde...." ifadesine yer verilmek suretiyle balıkçılığın tarım işi olmadığı ayrı bir iş olduğu kabul edilmiş gibi görünmektedir. Ancak burada anılan kanunun SGK'ya tescil edilecek işyerlerine göre işlem yaptığı bir başka deyişle işe değil işyerine odaklandığı da göz ardı edilmemelidir.

65 Ticari değere sahip süngerler iki şekilde elde edilmekte olup, bunlardan ilki, en eski ve yaygın olanı sünger avcılığ 1 diğeri ise daha sınırlı bir uygulama olan sünger yetiştiriciliğidir. Türkiye'de geçmişte olduğu gibi yakın yıllara kadar elde edilen süngerlerin tamamı avcılık olarak nitelendirilen, var olan ticari deniz sünger türlerinin çeşitli yöntemlerle avlanmasıyla temin edilmiştir. (ŞAHİN, s. 12). Bu nedenle süngercilik işiyle uğraşanların dahil oldukları kanun belirlenirken sünger avcılığı ve sünger yetiştiriciliği ayrımı yapmak gerekir.

66 SÜZEK, s. 176; UŞAN, s. 13. Kanaatimizce, İş Kanunu kapsamındaki süngerciliğin sünger yetiştiriciliği ile sınırlı tutulup, avcılık biçiminde yapılan süngerciliğin tipik bir balıkçılık faaliyeti olarak kabul edilmesi gerekir.

67 Dalyancılık, deniz, göl, ırmak gibi sularda, kıyılara yakın yerlerde su içinde çakılmış kazıklara gerilmiş ağlardan oluşturulan büyük, geniş balık avlama yerinde yapılan balık avcılığıdır (Türk Dil Kurumu Güncel Türkçe Sözlük, https://sozluk.gov.tr/, erişim tarihi, 09.09.2019.

68 GÜNAY, s. 244.

69 Danıştay İBK. 13.03.1972, 12/6, UŞAN'dan naklen, s. 12, dn. 41. Anılan kararda yapılan dalyancılık üretim değil sadece avlama biçiminde olmasından hareketle, salt balık avlama işinin tarım işi sayılmayacağına kanaat getirmiştir. 
işi kavramına hem balık üretme hem de avlama işi dahil edildiğinden, tarım işlerinin de İş Kanunu'na dahil edilmeyeceğinden, dalyancılık faaliyetinde çalışanların İş Kanunu kapsamında olmayacağını ifade etmektedir ${ }^{70}$. Varılan sonuç elbette ellinin altında çalışan sayısı olan dalyancılık faaliyetleri için geçerlidir. Bu durumda ise, aynı işi yapan büyük su ürünleri üreticilerine İş Kanunu uygulanırken, diğerlerine Türk Borçlar Kanunu'nun uygulanması sonucu ortaya çıkacaktır ${ }^{71}$. Öte yandan, su ürünleri üreticilerinin İş Kanunu kapsamında olduğu görüşünü paylaşan bir görüşe göre ise, İş K. m. 4/f bendi gereği, Deniz İş Kanunu kapsamına girmeyen ve tarım işinden sayılmayan su ürünleri üreticilerinin çalışan sayısı sınırına tabi olmaksızın İş Kanununa dahil olduğu gerekçesine dayanmaktadir ${ }^{72}$. Amaca daha uygun olan bu gerekçeye katıldığımızı belirtmekle birlikte, yukarıda bahsettiğimiz İş K. m. 111'de yer alan su ürünleri üreticilerinin de tarım işi yaptığını düzenleyen açık hüküm karşısında, varılan sonuç eleştiriye açıktır ${ }^{73}$. Aynı sorunun sadece su ürünleri üreticileri için değil, su ürünleri avcılığı yapanlar için de geçerli olduğu gerçeği karşısında kanaatimizce, tarım işi kavramının daraltılarak, su ürünleri üreticiliğinin ve özellikle de su ürünleri avcıllı̆ının bu kavramın kapsamı dışına çıkarılması daha isabetli olacaktır.

Yukarıda avcılık olarak kabul edilemeyen su ürünleri üreticiliğinin İş Kanunu kapsamında olduğunu belirledikten sonra, İş Kanunu m. 4/2-c'de düzenlenen "tarım sanatı" kavramı ile balıkçılık faaliyetini ilişkilendirmek gerekecektir. Tarımdan elde edilen ürünlerin işlenmesi biçiminde tanımlanan tarım sanatına, öğretide zeytinden zeytinyağı, sütten peynir, üzümden sirke yapılması biçiminde örnekler verilmekte ve anılan işler İş Kanunu kapsamında sayılmaktadır ${ }^{74}$. Yargitay eski tarihli bir kararında ise, tutulan balıkların tuzlanması ve işlenmesi faaliyetini tarım sanatı olarak kabul etmiştir ${ }^{75}$. Ancak günümüz modern balıkçılığı incelendiğinde, özellikle açık deniz balıkçılığ yapan büyük balıkçı gemilerinde balık avcılığının yanı sıra, tutulan balıkların

70 UŞAN, s. 13.

${ }^{71} \mathrm{Bu}$ durumun tüm tarım ve orman işi yapanlar için söz konusu olduğu ve eşitlik ilkesine aykırı olduğu yönündeki haklı eleştiri için bkz. CENTEL, s. 10-16.

72 GÜNAY, s. 244.

73 Uşan'a göre de, Deniz İş Kanunu'na girmemek koşuluyla denizlerde balık üretimi, yetiştirilmesi ve avcılığ tarım işi sayılmaktadır, (UŞAN, s. 12).

74 ÇELIKK /CANIKLİOĞLU /CANBOLAT, s. 156; AKTAY /ARICI /SENYEN KAPLAN, s. 48.

75 Y. 10. HD. 05.10.1976, E. 2003, K. 6763, NARMANLIOĞLU, s. 82. 
işlenmesi ve hatta paketlenmesi işlemlerinin de balıkçı gemisinde gerçekleştiği görülmektedir. Böylece, aynı gemide faaliyet gösteren çalışanların bir kısmının İş Kanunu kapsamı dışında olmalarına karşın, bir kısmının tarım sanatı yaptıkları gerekçesiyle İş Kanunu'na dahil edilmesi sonucu ortaya çıkmaktadır.

Nihayet, balık avcıllı̆ı işiyle uğraşan çalışanların tabi olduğu kanuna ilişkin değerlendirme yapmak gerekirse, ilk olarak balıkçılığın İş Kanunu'nda yer alan istisnalardan "deniz taşıma işi”" niteliği taşımadığından, doğrudan İş Kanunu kapsamı dışında olduklarını söyleyemeyiz. Maddenin son kısmında yer alan, "Deniz İş Kanunu kapsamına girmeyen ve tarım işlerinden sayılmayan, denizlerde çalışan su ürünleri üreticileri ile ilgili işler", hükmünü değerlendirdiğimizde, balıkçı̆̆ın Deniz İş Kanunu kapsamında olup olmadığına göre sonuca ulaşmak mümkündür. Deniz İş Kanunu'nun ${ }^{76}$ kapsamını belirleyen 1. maddesinde, "Bu kanun denizlerde, göllerde ve akarsularda Türk Bayrağını taşıyan ve yüz ve daha yukarı grostonilatoluk gemilerde bir hizmet akti ile çalışan gemiadamları ve bunların işverenleri hakkında uygulanır. "hükmünün yer aldığı bilinmektedir. Görüldüğü gibi bir geminin Deniz İş Kanunu kapsamına girmesi için üç temel koşulun birlikte mevcut olması gerekir. Bunlar; geminin deniz, göl veya akarsularda çalışıyor olması, Türk bayrăğ taşıması ve nihayet yüz ve daha fazla grostonilatoluk olmasıdır. Son koşul esnekleştirilerek, 1. maddenin devamına, "Aynı işverene ait gemilerin grostonilatolart toplamı yüz veya daha fazla olduğu veyahut işverenin çalıştırdığ gemi adamı sayısı 5 veya daha fazla bulunduğu takdirde birinci bent hükmü uygulanır." hükmü eklenmiştir. Böylece daha küçük boyuttaki ve daha az çalışanı bulunan gemiler de Deniz İş Kanunu kapsamına dahil edilmiştir.

Deniz İş Kanunu kapsamı belirlenirken, geminin hangi amaçla kullanılmakta olduğu önem arz etmediğinden, taşıma ${ }^{77}$, ticaret, turizm, eğitim, spor gibi farklı amaçlara hizmet eden gemiler de bu kanun kapsamına dahil edilmektedir ${ }^{78}$. O halde balıkçılık faaliyeti yürüten bir geminin de yukarıda

76 RG. 12586, 29/4/1967.

77 İş Kanunu'nda deniz taşıma işinin kapsamda olmadığı açıkça ifade edildiğinden, deniz taşıma işini yürüten bir geminin DİK.'da sayılan diğer koşuları da sağlamaktaysa Deniz İş Kanunu kapsamında değerlendirileceği kuşkusuzdur. Aynı yönde, KAR, ( Deniz İş), s. 132135.

78 BEDÜK, s.35; MOLLAMAHMUTOĞLU /ASTARLI /BAYSAL s. 71. Buna karşın Yargıtay'ın bir kararında, DİK kapsamına sadece deniz taşıma işlerinin girdiği yönünde bir kabule yer verilmiştir. Y. 9. HD., E. 2009/6543 K. 2009/12102 T. 28.04.2009, https://www. 
sayılan üç temel koşulu sağlamak kaydıyla Deniz İş Kanunu kapsamına dahil olması gerekmektedir ${ }^{79}$. Ancak bir balıkçı gemisinin Deniz İş Kanunu kapsamına dahil olamadığı durumlarda, örneğin yüz grostonilatonun altında olması gibi durumlarda, İş Kanunu'na mı yoksa Türk Borçlar Kanunu'na mı dahil olacağı sorusunun da yanıtlanması gerekmektedir. "Deniz İş Kanunu kapsamına girmeyen ve tarım işlerinden sayılmayan, denizlerde çalışan su ürünleri üreticileri ile ilgili işler", İş Kanunu kapsamına dahil olduğundan ve su ürünleri üreticiliği kavramına balık avc1lığ da dahil olduğundan ve İş Kanunu kapsamındaki tarım işi kavramına su ürünleri avcılığı da dahil olduğundan, ellinin altında çalışanı olan balıkçı gemileri Türk Borçlar Kanunu kapsamına dahil olurken, ellinin üzeri çalışanı olanlar İş Kanunu kapsamına dahil olacaktır. Ancak ellinin üzerinde çalışanı olan bir balıkçı gemisinin Deniz İş Kanunu kapsamına dahil olma olasılığının da çok yüksek olduğunu belirtmek gerekir. Öğretide bizim de katıldığımız görüşte olan, Bedük ve Dündar da, balıkçılık sektöründe çalışanların dahil olduğu kanun kapsamını belirlerken, öncelikle Deniz İş Kanunu kapsamında olup olmadıklarının değerlendirilmesi gerektiğini, bu kapsamda değillerse ve gerçekleştirdikleri faaliyet tarım işinden de sayılmıyorsa, Türk Borçlar Kanunu'nun uygulanacağını ifade etmektedir ${ }^{80}$. Yargıtay'ın da aynı görüş doğrultusunda kararları bulunmaktadır ${ }^{81}$. Narmanlıoğlu, açıklamasını sadece balıkçılığa özgülememekle birlikte, denizde yapılan fakat Deniz İş Kanunu kapsamına girmeyen işler hakkında İş Kanunu hükümlerinin uygulanması gerektiğini ifade etmektedir ${ }^{82}$. Kar ise, deniz taşıma işi sayılmayan ve tarım işi niteliğinde de olmayan balıkçılık faaliyetlerine İş Kanunu uygulanacağını ifade etmektedir. Ancak İş K anununda yer alan, "kara ve su avcıllğ üreticiliği ile bu yoldan elde edilen ürünlerin saklanması ve taşınması", biçimindeki geniş bir şekilde yapılmış tarım işi tanımı karşısında, deniz,

lexpera.com.tr/ictihat/yargitay/9-hukuk-dairesi-e-2009-6543-k-2009-12102-t-28-04-2009, erişim tarihi 12.09.2019.

79 Aynı yönde, SÜZEL, s. 193.

80 BEDÜK, s. 41-42; DÜNDAR, s. 143-144; KAR, (Deniz İş), s. 40.

81 Y. 7. HD. E. 2014/7013 K. 2014/15462 T. 07.07.2014, lexpera.com.tr. Bir başka kararda ise, 47,21 grostonilato olan gemide 2-3 işçinin balık avc1lı̆g 1 yapmakta olduğu gemide yapılan çalışmanın DİK'na tabi olmadığı ancak gemideki bu faaliyetin deniz tarımı kapsamında olup olmadığı, davacının İş Kanunu kapsamında kalıp kalmadığına buna göre karar verilmesi gerektiğine hükmedilmiştir. Y., 22. HD., E. 2016/15558 K. 2018/17619 T. 19.7.2018, lexpera.com.tr. Benzer içerikli bir karar, Y. 22. HD., E. 2017/7675 K. 2017/10768 T. 11.5.2017, lexpera.com.tr.

82 NARMANLIOĞLU, s. 80. 
göl ve akarsularda yapılmakta olan hangi balıkçılık faaliyetinin tarım işi sayılmayacağını belirlemek güçtür. Bu nedenle kanaatimizce balık avcılığ her durumda tarım işi sayılmaktadır. Ancak tarım işlerinin tamamı değil de bir bölümü İş Kanunu kapsamında olduğundan, DİK kapsamına girmeyen ve elli ve ellinin altında çalışanı olan balıkçı gemilerinde çalışanlar, aslında tarım işi yapmalarına karşın İş Kanunu'na değil, Türk Borçlar Kanunu'na tabi olacaklardır. Bu da ülkemizde sıklıkla görülen küçük çaplı kıyı balıkçılarının TBK kapsamına gireceği sonucunu doğuracaktır ${ }^{83}$. Ancak varılan bu sonucu olumlu bulan Kar'a göre, Deniz İş Kanunu'nda yer almayıp da, TBK'da yer alan ve işçi lehine olan pek çok hüküm bulunmaktadır ${ }^{84}$.

Sonuç olarak, balıkçılık sektöründe çalışan Deniz İş Kanunu, İş Kanunu ve Türk Borçlar Kanunu kapsamına dahil olan üç farklı çalışan grubu ortaya çıkmaktadır ki, uygulama birliği sağlama açısından olumlu sonuçlar doğurmayacağ 1 açıktır. Bu nedenle kanaatimizce 2006 Deniz Çalışma ILO Sözleşmesinin kabulünün ardından güncellenmesi beklenen Deniz İş Kanunu'na balıkçılık faaliyetiyle uğraşan tüm çalışanları dahil etmek isabetli olacaktır.

\section{Deniz İş Kanunu-İş Kanunu-Türk Borçlar Kanunu İlişkisi}

Farklı nitelikteki balıkçı gemilerinde çalışan balıkçılara farklı kanunların uygulanacağı tespit edildikten sonra dahi, Deniz İş Kanunu kapsamında olan bir balıkçıya bu kanunda hüküm bulunmaması durumunda İş Kanunu mu yoksa Türk Borçlar Kanunu mu uygulanacağı sorusunu da yanıtlamak gerekmektedir. Diğer bir ifade ile, Deniz İş Kanunu ile İş Kanunu ve Türk Borçlar Kanunu arasındaki ilişski ortaya konulmalıdır. İlk olarak Deniz İş Kanunu ile İş̧ Kanunu arasındaki ilişkiyi belirleyecek olduğumuzda, öğretide görüş birliği olmadığı, bir görüşün Deniz İş Kanunu'nda hüküm bulunmayan hallerde TBK'nın uygulanacağını zira DİK' da İş Kanunu'nun genel nitelikte bir kanun olduğu yönünde bir ifade yer almadığı gibi sadece istisnai ${ }^{85}$ bazı durumlarda

83 Oysa 4857 sayılı Kanunda yapılan değişikliğin amacı, "su ürünleri üreticilerinin” İş Kanunu kapsamına dahil ederek, kıyı şehirlerimizde rastlanan, kolsuz veya tek bacaklı olarak adlandırılan küçük çaplı balık avcılarının da İş Kanunu kapsamına alınmasını sağlamak olduğu yasanın kabulü esnasında Meclis görüşmelerinde dile getirilmiştir (YÜREKLİ, s. 629). Ancak Deniz İş Kanunu kapsamına 5'den fazla çalışanı olan gemiler girdiğine göre, küçük çaplı balıkçı teknesi kavramı da beşten az çalışanı olan tekneler için kullanılacaktır.

84 KAR, (TBK), s 170.

85 Örneğin DİK.m.49'da açıkça İş K.'daki çalışma hayatının teftiş ve denetimi ile ilgili maddelerin uygulanacağ 1 belirtilmiştir. 
İş Kanunu hükümlerinin uygulanacağ 1 yönünde olduğu görülmektedir ${ }^{86}$. Diğer görüşe göre ise, İş Kanunu'nun 1. maddesinde, 4. maddede sayılan istisnalar dışında kalan tüm iş ilişkilerine İş Kanunu uygulanacağı hükmüne yer verilerek, işçiyi koruyucu nitelikte hükümler bakımından İş Kanunu'nun gerisinde kalan DİK'na tabi çalışanlara, hüküm bulunmayan durumlarda İş Kanununun uygulanmasi gerekmektedir ${ }^{87}$.

Kanaatimizce, İş Kanunu'nun DİK'na göre genel nitelikte olduğu görüşüne katılmamak gerekir. İlk görüşü savunanların belirttiği üzere, sadece istisnai durumlarda İş Kanunu'na atıf yapılması bunun sonucu olarak karşımıza çıkmaktadır. TBK'nun genel ve yeni tarihli olma özellikleri dikkate alındığında, DİK.'da hüküm bulunmayan hallerde genel Kanun olan TBK'ya gitmek gerekmektedir. TBK' daki genel hükümlerin balıkçılık gibi spesifik bir çalışmanın ihtiyacını karşılamada yetersiz kalma olasılığ karşısında ise, 188 sayılı Sözleşmenin iç hukukumuza dahil edilmesi gerektiği sonucu bir kez daha ortaya çıkmaktadır. Her ne kadar uluslararası sözleşmelerin kanunun üzerinde olduğu yönündeki Anayasal esas mevcut olsa da, sözleşmenin iç hukuka yansıtılmasıyla 188 sayılı Sözleşmenin sorunsuz ve daha pratik bir biçimde uygulanması sağlanacaktır.

Deniz İş Kanunu ile Türk Borçlar Kanunu ilişkisi değerlendirildiğinde ise, şayet İş Kanunu ile DİK.'nu özel kanunlar olarak değerlendirirsek, genel kanun TBK. olacak ve dolayısıyla DİK'da hüküm bulunmayan hallerde TBK uygulanacaktır. Bu görüşü savunan Kar, yaptığı tespitte pek çok TBK. hükmünün DİK'da düzenleme yer almayan konularda uygulanacağını ifade etmiştir ${ }^{88}$.

\section{3. İkincil Mevzuat}

Balıkçl1ık sektöründe çalışanlara yönelik düzenlenen ikincil mevzuat genellikle yönetmelik biçiminde karşımıza çıkmaktadır. Bunlardan biri, "Balıkçı Gemilerinin Emniyeti Hakkında Yönetmelik"tir". Bu yönetmelik,

86 ÇELIK/CANIKLİOĞLU/CANBOLAT, s. 21; SÜZEK, s. 34; GÖKÇE, s. 741; KAR, (Deniz İş), s. 40; BEDÜK, s. 43.

87 CENTEL, (1994), s. 19; ULUCAN, s. 13. Bu yönde, Y. 9. HD., 04.05.1968, 431/377, KAR, (TBK), s. 168.

88 KAR, (TBK), s. 171-176.

89 RG. 26089, 23.02.2006.Yönetmelik, 01.07.2012 tarihi itibariyle yürürlüğe girmiştir. Anılan Yönetmelik, 97/70/EC sayılı Avrupa Birliği Direktifi hükümlerine paralel olarak hazırlanmıştır. Yönetmelik ayrıca "Türk balıkçı gemilerinin bu Yönetmeliğin Ek-I'inde aksi 
boyu 24 metreden fazla olan Türk bayrakl1, Türk iç sularında veya kara sularında çalışan, yakaladıkları avları bir Türk limanına getirip bırakan mevcut balıkçı gemileri için emniyet standartlarını oluşturmak ve balıkçı gemilerinin emniyeti konusunda ulusal uygulamalarla ilgili yetki, görev ve sorumluluklar ile uygulama usul ve esaslarını belirlemektedir ${ }^{90}$. Bu yönetmelik balıkçı gemileriyle ilgili kurallara yönelik olduğundan, doğrudan balıkçılık faaliyetinde çalışanların haklarına ilişkin düzenlemeler içermemektedir.

Diğer Yönetmelik ise, Balıkçı Gemilerinde Yapılan Çalışmalarda Sağlık ve Güvenlik Önlemleri Hakkında Yönetmelik'tirri1. Yukarıda da bahsetmiş olduğumuz bu yönetmelik, 6331 sayılı İş Sağlı̆ğ ve Güvenliği Kanunu gereği alınması gereken tedbirleri açıklamak üzere, balıkçı gemilerinde yapılan işlerde çalışanların sağlık ve güvenliğinin korunması için alınması gereken önlemleri belirlemeyi amaçlamaktadır (Y.m.1) ${ }^{92}$. Bu yönetmelikte, Çalışanların görüşlerinin alınması ve katılımlarının sağlanması, eğitimi ve bilgilendirilmesi gibi konularda, İş Sağlığı ve Güvenliği Kanunu hükümleri saklı kalmak kaydıyla yönetmelikteki esasların uygulanacağı ifade edilmiştir. Ancak aşağıda inceleyeceğimiz sağlık muayenesine ilişkin özel bir düzenlemeye yer verilmediği görülmektedir. Bu durumda, bu konuda İş Sağlı̆̆ 1 ve Güvenliği Kanunu'ndaki hükümlerin uygulanacağı sonucu ortaya çıkmaktadır.

Gemiadamlarına yönelik bir yönetmelik olan, Gemiadamları ve Kılavuz Kaptanlar Yönetmeliğ $i^{93}$ ise, 1. maddesindeki düzenlemeye göre, "gemiadamları ve kılavuz kaptanların yeterlikleri, eğitimleri, sınavları, belgelendirilmeleri, sağlik durumları, elektronik kayıt işlemleri, vardiya tutmalarına ilişkin kuralları ve disiplin işlemleri ile gemiadamlarına ilişkin denizcilik eğitimi veren kurum ve kuruluşlara yönelik idari yaptırımları düzenlemekte" ve bu gemiadamları arasında balıkçı sınıfı gemiadamlarına da değinmektedir.

\footnotetext{
belirtilmedikçe, Torremolinos Protokolü Eki hükümlerine uyulması zorunluluğu getirmiştir."

90 TANTOĞLU, s. 25.

91 RG. 28741, 20.08.2013.

92 Yönetmelik kapsamına İş Sağlığı ve Güvenliği Kanunu kapsamına giren tüm balıkçı gemileri girmektedir. Yönetmeliğin yürürlükten kaldırılan 2004 tarihli önceki şeklinde ise kapsam, "İş Kanunu kapsamına giren balıkçı gemileri olarak belirlenmişti.

$93 \quad$ RG. 30328, 10.02.2018.
} 
Konuyla ilgili bir diğer yönetmelik ise, Gemiadamlarının İkamet Yerleri, Sağllkve Iaşselerine Dair Yönetmelik'tir ${ }^{94}$. Ancak bu yönetmelik, 2. maddesinde, "500 grostonilatodan daha küçük gemilerle, balık avı ve benzeri işlerde çalışan gemiler, römorkörler ve yüzer vinçler dişında 854 sayılı Deniz İş Kanunu'nun kapsamına giren gemiler ile bu gemilerde çalışan gemiadamları, bunların işverenleri ve işveren vekillerini kapsar." demek suretiyle balıkçı gemilerinin büyüklüğüne bakılmaksızın bu yönetmelik kapsamında olmadığını açıç̧a ifade etmiştir.

Sözü edilen Yönetmeliklerin genellikle balıkç1lık faaliyeti yürüten çalışanların iş sağlığı ve güvenliğine ilişkin düzenlemeler yaptığı görülmektedir. Oysa balıkçılık faaliyetinin kendine has bir mevsimlik iş olma özelliği dikkate alındığında, gerek iş sözleşmesi gerekse çalışma koşulları konusunda özel düzenlemelere de ihtiyaç duyulduğu kuşkusuzdur. İşte bu noktada 188 sayılı ILO Sözleşmesinde bahsedilen konuları düzenleyen hususların iç hukukumuza dahil edilerek yönetmelik olarak çıkarılması isabetli olacaktır. Örneğin 188 sayılı Sözleşmede balıkçıların iş sözleşmelerinin nasıl düzenlenmesi gerektiğine yönelik detaylı açıklamalar yapılmışken, hukukumuzda bu konu ya Deniz İş Kanunu'ndaki ya da İş Kanunu veya Türk Borçlar Kanunu'ndaki iş sözleşmelerine ilişkin genel kurallara göre yapılmaktadır.

\section{188 Sayılı Balıkçılık Çalışma ILO Sözleşmesinde Düzenlenen Hükümlerin Ulusal Mevzuatta Yer Alan Düzenlemelerle Karşılaştırılması}

\section{A. Genel Olarak 188 Sayılı Sözleşme İçeriği}

Toplamda 54 madde ve eklerden oluşan 188 sayılı Sözleşmede, 9 temel bölüm yer almaktadır. Bunlar; tanımlar ve kapsam, genel ilkeler, balıkçı gemilerinde çalışma için gereken asgari şartlar, hizmet koşulları, konaklama ve yemek, tıbbi bakım ve sosyal güvenlik, uygulama, eklerde yapılan değişiklikler ve nihai hükümlerdir. Ayrıca sözleşmeye ek olarak üç temel konu başlı̆g 1 düzenlenmiştir. Bunlar; gemi ölçüm birimlerinde denklik sağlamaya yönelik hükümler, balıkçıların iş sözleşmesinde bulunması gereken hususlar ve nihayet balıkçı teknesinde konaklamaya ilişkin hususlardır.

Yukarıda da değinildiği gibi sadece Deniz İş Kanunu kapsamında olmayan balıkçıların, kendilerine uygulanan ulusal mevzuat hükümleriyle 188 sayılı ILO sözleşmesinde yer alan bu haklardan ne ölçüde yararlandıklarını

$94 \quad$ RG. 20378, 20.12.1989. 
tüm sözleşme maddeleri için ayrı ayrı değerlendirmek çalışmamızın kapsamını oldukça genişleteceğinden, değerlendirmelerimizi sadece sözleşmenin ilk bölümünde yer alan "kapsam" ve üçüncü bölümünde yer alan "balıkç1 gemilerinde çalışmak için gereken asgari koşullar”a özgüleyeceğiz.

188 Sayılı Sözleşmeye bakıldığında, sosyal diyalogun ve üçlü istişarenin önemini vurgulamakta olduğu görülmektedir. $\mathrm{Bu}$ nedenle pek çok hüküm ancak işverenlerin ve işçi örgütleriyle (özellikle balıkçı teknesi sahiplerinin ve balıkçıları temsil eden kuruluşlar) yapılan "istişarenin ardından" uygulanabilir ${ }^{95}$. İnceleyeceğimiz maddelerde de istişare gerektiren hükümler söz konusudur.

\section{B. Sözleşmenin Kapsamı}

188 say1lı Sözleşmenin ilk bölümünde yer alan ve bu sözleşmenin hangi balıkçılık faaliyetlerine uygulanacağını açıklayan $2,3,4$ ve 5. maddeleri incelenerek sözleşme koruması altında olan çalışanları belirlemek gerekir. İlk olarak oldukça geniş bir ifadeye yer verilerek, "işsbu sözleşmede aksi belirtilmediği sürece, bu Sözleşme tüm balıkçılar ve ticari balıkçılık faaliyetlerinde bulunan tüm balıkçı gemileri için geçerlidir." şeklinde düzenleme yapılmıştır (m. 2/1). Maddede yapılan tek sınırlamanın balıkçı1lı̆ın amacı yönünde olduğu ve sadece ticari balıkçığı kapsamına aldığı görülmektedir. Yapılan işin ticari balıkçılık olup olmadığı hususunda bir tereddüt ortaya çıktığında, yetkili makamın yaptığı değerlendirme sonrası karar verilecektir (m. 2/2).

Ulusal mevzuatımızda ise, uygulanacak kanun hükmü belirlenirken balıkçılığın ticari olup olmadığ kriteri yerine "tarım işis" olup olmadığ 1 üzerinde durulduğu görülmektedir. Bu durum yukarıda da belirtildiği gibi dahil olunacak kanunu belirlemede sorunlara yol açabilmektedir. 188 sayılı Sözleşmede, ticari balıkçılık için, hobi ve geçimlik amaçlı yapılan balıkçılık dışındaki tüm balıkçılık faaliyetlerini kapsar yönünde bir tanıma yer verildiğinden, aslında oldukça geniş bir kesimi kapsamına dahil ettiği söylenebilir.

Maddenin devamında, Sözleşme taraflarına bu sözleşme hükümlerinin tamamını ya da bir kısmını 24 metreden daha kısa balıkçı gemilerine de

95 ILO Work in Fishing Convention and Recommendation, 2007

Action Plan 2011-2016, International Labour Office Geneva, 2011, s. 3 https://www.ilo. org/wcmsp5/groups/public/---ed_dialogue/---sector/documents/publication/wcms_161220, erişim tarihi, 05.10.2019. 
uygulayabilme inisiyatifi verilmiştir. Görüldüğü gibi kapsamı belirleme konusunda Sözleşme hükümlerinin oldukça esnek bir şekilde belirlendiği söylenebilir ${ }^{96}$. Zira sözleşmenin 3. maddesinin 1. fikrasında, uygulamada sorunlar çıkacağ1 düşünüldüğ̈̈nde, taraf devletlerin, "nehir, göl veya kanallarda balıkçılıkla uğraşan balıkçı tekneleri ile sınırlı kategoride balıcçı veya balıkçı teknelerini bu sözleşmenin gereklilik veya hükümlerinden bazıları ile ilgili olarak kapsam dışı bırakabilmesine olanak sağlamaktadır."

"Sınırlı kategorideki işçiler” deyiminin salt 188 sayılı Sözleşmeye özgü olmadığıını, ILO’nun pek çok sözleşmesinde de bu yönde sınırlı kategoriler belirlendiği bilinmektedir ${ }^{97}$. Ancak, istisnalar, yalnızca Sözleşme'nin gerekliliklerini yerine getirmek için alternatif bir çözüm bulunamadığı önemli nitelikteki sorunların ortaya çıkması durumunda yapılmalıdır ${ }^{98}$.

Ülkemizin 188 sayılı Sözleşmeye taraf olması durumunda, yukarıda belirtilen sinırlamalardan hukuk sistemimiz ve uygulamaya en uygun olanını tercih etmesi ve en azından kademeli olarak tüm balıcçı gemilerini kapsama alması yararlı olacaktır.

\section{Balıkçı Gemilerinde Çalışmak İçin Gereken Asgari Koşullar}

Sözleşmenin üçüncü bölümünde yer alan asgari koşullar iki temel başlık altında ele alınmış ve ilk olarak balıkçı gemilerinde çalışabilmek için asgari yaş koşulu getirilmiştir. İkinci koşul olarak da, çalışanların tıbbi muayeneden geçirilmesi düzenlenmiştir.

199 sayılı Tavsiye Kararında da benzer içerikli olarak balıçı gemilerinde çalışmak için aranan koşullar düzenlenmiş ve gençlerin korunması, tıbbi muayene, yetkinlik ve eğitim olmak üzere üç başlık altında taraf devletlere tavsiyelerde bulunulmuştur.

96 ILO'nun Balıkçılık sektöründeki çalışmaya ilişkin IV-(2A) sayılı raporu incelendiğinde, pek çok ülkenin (Fransa, Arjantin, Çin Belçika, Brezilya) kapsama ilişkin esnek hükümlere sıcak bakmadığı söylenebilir. İstisnai olarak Almanya'nın bağımsız çalışan balıkçılar açısından bu gruptakilerin kapsam dışı tutulması gerektiğini ifade ettiği görülmektedir (https://www.ilo.org/public/english/standards/relm/ilc/ilc96/pdf/rep-iv-2a.pdf, s. 11, erişim tarihi 11.09.2019.).

97 Örneğin, 158 sayılı Sözleşmenin Sona Ermesine İlişki ILO Sözleşmesinin 2/5. maddesinde de iş güvencesinin işletmenin büyüklüğü veya yapılan işin niteliğine göre sınırlı işçi kategorileri için uygulanmamasına karar verilebileceği düzenlenmiştir.

98 ILC, 81. Oturum, 1994, Bildiri kayıtlar1, paragraf 61, s. 23/18. 


\section{Asgari Yaş}

Balıkçılık faaliyetinin oldukça güç çalışma koşullarında yapıldığı gerçeği göz ardı edilemeyeceğinden, belirli yaşın altındaki çalışanların bu faaliyeti yürütmemesi aslolandır. Ancak çocuk işçiliği balıkçılık sektöründe de sıklıkla görülen bir sorun olduğundan, FAO ve ILO bu konuda özel düzenlemeler içeren çalışmalar yapmaktadır ${ }^{99}$. Balıkçı gemilerinde çalışabilmek için gereken asgari yaş, Sözleşme'nin 9. maddesinde üç farklı biçimde belirlenmiştir. Buna göre, genel yaş sınırı, asgari 16 yaş olacaktır ${ }^{100}$. Bununla birlikte, yetkili makam, ulusal mevzuatın sağladığı zorunlu eğitime tabi olmayan ve balıkçılıkta mesleki eğitim yapan kişiler için bu sınır en az 15 yaş olarak belirlenebilir ${ }^{101}$ (m. 9/1). Ancak 15 yaşını dolduranların yapabileceği işler okul tatillerinde olmak kaydıyla hafif nitelikli işler olacaktır (m. 9/2). Bu konuda belirlenen üçüncü yaş sınırı ise, 18 yaştır. Balıkçılık faaliyetinin doğası gereği ya da içinde bulunulan özel durumda gençlerin sağlık, güvenlik ve ahlaki durumlarını tehlikeye atacak nitelikte işlerde bu yaş sınırı geçerli olacaktır (m. 9/3).

4857 sayılı Kanun' da yer alan asgari yaşa ilişkin düzenlemelerin 188 sayıl1 ILO sözleşmesinde düzenlenen hükümlerden farklı olduğu görülmektedir. İş K.m.71'e göre genel asgari çalışma yaş1 15 yaşın doldurulmasıdır ${ }^{102}$. Ancak

99 Örneğin ILO ve FAO, 14-16 Nisan 2010 tarihinde Roma'da ortak bir çalışma yürüterek, balıkçılık sektöründeki çocuk işçiliğinin nedenleri, etki ve sonuçlarını belirlemeye çalışmışlardır. Anılan çalıştayda dikkat çeken husus, üye devletlere ülkelerinde öncelikle balıkçılık sektöründe çalışan çocuklara yönelik bir risk değerlendirmesi yapıp, ardından çıkan sonuç doğrultusunda ulusal mevzuatlarında gereken tedbirleri almaları önerildi. Ayrıca hükümetlere, balıkçılık sektöründe çalışan çocukların zorla çalıştırılmasının önlenmesi için çağrıda bulunuldu. Report of the FAO Workshop on Child Labour in Fisheries and Aquaculture in Cooperation with ILO, Rome, 14-16 April 2010, s. 3, http://www.fao.org/3/ i1813e/i1813e00.htm, erişim tarihi, 13.09.2019.

100 1999/63 EC sayılı Deniz İşçilerinin Çalışma Sürelerine İlişkin Konsey Direktifinin 11. maddesinde de, 16 yaşından küçüklerin gemide çalıştırılamayacağı düzenlenmiştir. Anılan Yönerge, Avrupa Topluluğu Armatörler Birliği (ECSA) ve Avrupa Birliği Ulaştırma İşçileri Sendikaları Federasyonu (FST) ELI tarafindan imzalanmıştır. https://eur-lex.europa.eu/ legal-content/EN/TXT/?uri=CELEX:01999L0063-20090520, erişim tarihi 21.09.2019.

101 Bu istisna, 1973 tarihli 138 sayılı Asgari Yaş ILO Sözleşmesi hükümleriyle tutarlı olarak kabul edilmiştir. Bu sözleşme Türkiye'de 30.10.1998 tarihinden itibaren yürürlükte olup, genel asgari çalışma yaş1 15 olarak belirlenmiştir.

102 İş K. m. 71; "On beş yaşını doldurmamış çocukların çalıştırılması yasaktır. Ancak, on dört yaşını doldurmuş ve zorunlu ilköğretim çağını tamamlamış olan çocuklar; bedensel, zihinsel, sosyal ve ahlaki gelişmelerine ve eğitime devam edenlerin okullarına devamına engel olmayacak hafif işlerde çalıştırılabilirler. On dört yaşını doldurmamış çocuklar ise bedensel, zihinsel, sosyal ve ahlaki gelişmelerine ve eğitime devam edenlerin okullarına 
Gemiadamları ve Kılavuz Kaptanlar Yönetmeliği’nin 27. maddesinde balıkçı gemisi güverte tayfası yeterliği almak için müracaat edenlerden; "On sekiz yaşını bitirmiş olmak" koşulu arandığı görülmektedir. Maddenin devamında, balıkçı gemisi kaptanı yeterliği almak için on sekiz yaşını bitirmiş olmak ve açık deniz balıkçı gemisi kaptanı yeterliği almak için ise yirmi yaşını bitirmiş olmak koşulları aranmaktadır.

Bir deniz aracında çalışan kişinin gemi adamı niteliğinde olması o deniz aracının büyüklügüne göre belirlenmekte ve Gemilerin Gemiadamları İle Donatılmasına İlişkin Yönerge'de belirtildiği üzere 50 net tondan büyük her gemi ile talep halinde tonajına bakılmaksızın bütün gemiler bu yönergedeki çizelgelere göre Ek-1'de belirtilen örneğe uygun olarak "Gemiadamları Donatımında Asgari Emniyet Belgesi” almak zorundadır (m. 4). İşs mevzuatımıza göre gemi adamı olmak için gemide iş sözleşmesiyle istihdam edilmiş olmak yeterli olduğundan ${ }^{103}$, tüm balıkçı gemilerinde/teknelerinde çalışanların gemi adamı olduğunu söylemek mümkündür. Böylece dahil olduğu kanunun DİK, TBK veya İş Kanunu olmasına bakılmaksızın balıkçılık yapan tüm gemiadamları açısından Gemiadamları ve Kılavuz Kaptanlar Yönetmeliğinde belirtilen asgari yaş sınırları uygulanacaktır. Böylece 188 sayılı Sözleşmenin ötesinde bir düzenleme yapılarak, 15 ve 16 yaşlar değil sadece 18 yaşından büyüklerin balıkçı sınıfı gemi adamı olması mümkün k1lınmıştır.

Deniz İş Kanunu'nda ${ }^{104}$ ve TBK'da asgari yaşa ilişkin özel bir düzenleme de bulunmamaktadır ${ }^{105} .2006$ ILO Deniz İş Sözleşmesi her ne kadar balıkçı1ık sektöründe uygulanmasa da, bu sözleşmede de gemi adamı açısından kabul edilen asgari yaş 16 olarak belirlenmiştir.

Denizde yapılan işlerin doğası gereği tehlikeli nitelikte olması, 138 sayılı Asgari Yaş ILO Sözleşmesi’nin 3/1. maddesinde belirtildiği üzere, "gençlerin

devamına engel olmayacak sanat, kültür ve reklam faaliyetlerinde yazıll sözleşme yapmak ve her bir faaliyet için ayrı izin almak şartıyla çalıştırllabilirler."

103 KARAN/AKIN, s. 719

104 Kanaatimizce Deniz İş Kanunu'nda asgari çalışma yaşına ilişkin özel bir düzenleme yapılmamış olması büyük bir eksikliktir. Bu eksikliğin 2006 Deniz Çalışma ILO Sözleşmesinin kabulünün ardından tamamlanması isabetli olacaktır.

105 TBK kapsamındaki işçiler açısından asgari yaşa ilişkin düzenleme bulunmadığından Umumi Hıfzıssıhha Kanunu hükümlerine gidilmesi gerektiği ancak anılan eski tarihli kanunun da günümüz ihtiyaçlarını karşılamadığı için eleştirilebileceği yönünde, ÖZKARACA/ÜNAL, s. 371; Ayn1 yönde, BAKIRCI, s. 229. 
sağlığını, güvenliğini veya ahlâkını tehlikeye atacak herhangi bir iş veya işe giriş için asgari yaş 18 yaşından küçük olamaz." hükmü doğrultusunda gemi adamı olunabilecek yaş konusunda 18 yaş sınırının getirilmiş olması isabetlidir ${ }^{106} .188$ sayılı Sözleşmede de aynı doğrultuda hareket edilerek 9/3. maddesinde, "Balıkçı gemilerinde, doğası gereği ya da içinde bulundukları şartların tehlikeye girme olasıllğ̆ olan gençlerin sağllk, güvenlik veya ahlaki durumlarını tehlikeye atacakları faaliyetlerde çalışanların asgari yaşı 18 yaşından küçük olmayacaktır." ifadelerine yer verilmiştir ${ }^{107}$. Böylece ulusal hukukumuzda yer alan 18 yaş sınırı ile 188 sayılı Sözleşmeye uygun hatta onun daha üzerinde bir düzenleme yapmış olduğumuzu söyleyebiliriz.

Asgari çalışma yaşına ilişkin bir diğer husus da, gece çalışmaya ilişkindir. Sözleşmenin 9/6. maddesinde, 18 yaşından küçüklerin balıkçı gemilerinde gece çalışması yapması yasaklanmışıır ${ }^{108}$. Maddenin uygulanmasında, "gece" ulusal yasa ve uygulamaya göre tanımlanacaktır. Ancak en geç 24:00'da başlayıp, en erken saat 5:00' de biten ve en az 9 saat süren bir zaman periyodunu kapsayacak biçimde belirlenmelidir"109. Maddenin devamında, "Yetkili makam gece çalışması ile ilgili katı uygulamanın kısıtlanmasına aşağıdaki durumlarda istisna getirebilir; (a) Ilgili gemiadamlarının mevcut programları çerçevesinde yapılması kararlaştırılan fiili eğitimlerinin tehlikeye düşmesi durumunda veya, (b) görevin doğası veya kararlaştırılmış bir eğitim programı gereği istisna getirilen gemiadamlarının gece çalışmasının öngörülmesi ve yetkili makamın ilgili armatör ve gemiadamları örgütlerine danıştıktan sonra, bu işin gemiadamlarının sağlı̆̆ına ya da refahlarına zarar vermediğini kararlaştırması durumunda." şeklinde iki istisnaya yer verilmiştir ${ }^{110}$.

106 ÖZKARACA/ÜNAL, s. 370; BAYRAM, s. 72-73.

107 Maddede bahsedilen tehlikeli durumlara, geminin kapalı alanlarında yapılan gürültüye, titreşime maruz kalınan işler, ağır yüklerin elle taşınması, ağların çıkarılması gibi işler örnek olarak gösterilebilir (ILO Handbook For Improving Living And Working Conditions On Board Fishing Vessels, Geneva, 2010, s. 60https://www.ilo.org/wcmsp5/groups/ public/---ed_dialogue/---sector/documents/publication/wcms_162323.pdf, erişim tarihi, 25.09.2019,).

108 Aynı yasağa, 1999/63 EC sayılı Denizcilerin Çalışma Sürelerine İlişkin Direktifí' in 6/1. maddesinde de rastlamaktayı.

109 İş K. m. 69/1'de ise gece tanımı daha farklı olarak şu şekilde yapılmıştır; "Çalışma hayatında "gece" en geç saat 20.00'de basslayarak en erken saat 06.00'ya kadar geçen ve her halde en fazla onbir saat süren dönemdir."

110 Benzer içerikli gece çalışma yapılmasına yönelik istisnaya 1999/63 sayılı EC Direktifte de yer verilmiştir. 
Ulusal mevzuatımıza baktı̆̆ımızda, İş Kanunu'nda sadece sanayie ait işlerde 18 yaşını doldurmamış olanların gece çalışması yasaklanmıştır (m.73/2). Ancak bu hüküm doğrudan balıkçılara uygulanacak nitelikte değildir. Bunun dışında, kadın çalışanlara ilişsin olarak, Kadın Çalışanların Gece Postalarında Çalıştırılma Koşulları Hakkında Yönetmelik'11 te kadın çalışanların gece çalışması tamamen yasaklanmamakla birlikte bu nitelikteki çalışanlar için özel düzenlemeler getirilmiştir. Ülkemiz uygulamasında balıkçılık sektöründe çalışan kadın sayısının az olduğundan, bu yönetmelik hükmünün de yaygın uygulaması olduğunu söylemek güçtür ${ }^{12}$.

Deniz İş Kanunu'nda ise gece çalışması yapılamayacağına ilişkin bir düzenleme bulunmamaktadır ${ }^{113}$. Zira denizde yapılan işler özellikle de balıkç11ı faaliyeti doğası gereği gece veya gündüz yapılması gerekebilecek nitelikte işlerdir. Gece çalışmaya ilişkin bir diğer ILO Sözleşmesi ise 180 sayılı Gemiadamlarının Çalışma Saatleri ve Gemide Çalışma Sözleşmesi'nin 6. maddesinde de aynı yasak yer almaktadır ${ }^{114}$. Bu sözleşmeye ülkemiz taraf olmadığından, Deniz İş Kanunu'nda benzer içerikli bir düzenlemenin olmaması beklenen bir sonuç olarak karşımıza çıkmaktadır. Ancak 2006 Deniz Çalışma Sözleşmesinin gece çalışmaya ilişkin yaptığı düzenlemeler ile 188 sayılı ILO Sözleşmesinin düzenlemelerini karşılaştırdığımızda birbirinin aynısı olduğu görülmektedir ${ }^{115}$. He ne kadar Deniz Çalışma Sözleşmesi

111 RG. 28717, 24.07.2013. Anılan Yönetmelik 6331 sayılı Kanun kapsamına giren işyerlerinde uygulanacaktır.

112 AB'nin 2002'de çıkardığı rapora göre avcılık ana sektöründe Avrupa Birliği üyesi ülkeler arasında en çok kadın balıkçı \%7 ile Yunanistan'dadır. Türkiye'de ise tekne üzerinde çalışan kadın balıkçılarla ilgili herhangi bir sayısal resmi kayıt yoktur. Balıkçılık mesleği erkek meslekleri arasında kabul edildiğinden yönetim planlarında da cinsiyet dengesi gözetilmemektedir (Heinrich Böll Stinftung Derneği Türkiye Temsilciliği, Toplumsal Cinsiyet Balıkçılık Sektöründe Kadınlar, https://tr.boell.org/tr/2017/06/07/toplumsalcinsiyet-balikcilik-sektorunde-kadinlar, erişim tarihi 24.09.2019).

113 Deniz İș Kanunu'nda çalıșma sürelerine ilișkin tüm düzenlemelerin herhangi bir fark oluşturulmaksızın gece çalışmalar içinde geçerli olacağı sonucu ortaya çıkmaktadır. (ASTARLI, s. 266).

114 Anılan Sözleşme, 1996 yılında kabul edilmiştir. Türkiye bu sözleşmeye de taraf değildir. Sözleşme genel olarak gemi adamlarını konu edinse de, Uygulanabilir gördüğü ölçüde, balıkçı teknesi sahiplerinin ve balıkçıların temsilci kuruluşlarına danıştıktan sonra, yetkili otorite, bu Sözleşmenin hükümlerini ticari deniz balıkçılığına uygulayacaktır (m. 1/2).

1152006 Deniz Çalıșma Sözleșmesi Standart A1. 1. 2-3.”Onsekiz yașından küçük bir gemi adamının gece çalışması yasaktır. Yetkili makam gece çalışması ile ilgili katı uygulamanın kısıtlanmasına aşağıdaki durumlarda istisna getirebilir; (a) İlgili gemi adamlarının mevcut programları çerçevesinde yapılması kararlaştırılan fiili eğitimlerinin tehlikeye düşmesi durumunda veya, (b)görevin doğası veya kararlaştırılmış bir eğitim programı gereği istisna 
balıkçıları kapsamasa da, ülkemizce onaylanmış olan Deniz Çalışma Sözleşmesi gereği gece çalışmaya ilişkin hükümlerin Deniz İş Kanunu'na dahil edilmesi gerekmektedir.

Nihayet, onsekiz yaşından küçükler bakımından getirilen bir diğer sınırlama da, 199 sayılı Tavsiye kararındaki, çalışma saatlerinin, günde sekiz saati ve haftada 40 saati geçmemesidir. Ayrıca güvenlik nedeniyle kaçınılmaz olan durumlar dışında, fazla mesai yaptırılmaması, günlük en az bir saat yemek molası izni verilmesi gerektiği yönünde düzenleme de bulunmaktadır (Bölüm I-4, 5).

\section{Tibbi Muayene}

188 sayılı Sözleşmede yer alan düzenlemelerden biri de, balıkçı gemilerinde çalışabilmek için tıbbi muayeneden geçirilmiş olmak koşulunu sağlanmasına ilişkindir ${ }^{116}$. Sözleşmenin 10. maddesinde yer alan düzenlemeye göre, "Hiçbir balıkçı, görevlerini yerine getirmeye uygunluğu gösteren geçerli bir sağllk sertifikası olmadan bir balıkçı teknesinde çalışamaz." Balıkçılık faaliyetinin doğası gereği tehlike içermesi ve insan sağlığını olumsuz etkileyebilecek koşullarda yapılması nedeniyle böyle bir zorunluluk getirilmiştir ${ }^{117}$. Ancak maddenin devamında taraf devletlere anılan yükümlülüğe bazı durumlarda bu maddenin uygulamasında balıkçılık yapılan alan veya balıkçılık türüne göre muafiyet verme hakkı tanınmaktadır ${ }^{118}(\mathrm{~m}$. 10/2). Ancak bu muafiyet 24 metreden uzun veya üç günden fazla denizde kalan balıkçı gemileri için söz konu olmayacaktır (m10/3). Acil durumlarda, yetkili makam, balıkçının daha önce almış olduğu ancak süresi dolmuş olan

getirilen gemi adamlarının gece çalışmasının öngörülmesi ve yetkili makamın ilgili armatör ve gemiadamları örgütlerine danıştıktan sonra, bu işin gemi adamlarının sağlığına ya da refahlarına zarar vermediğini kararlaştırması durumunda."

116 Tıbbi muayene konusunda ILO ve IMO'nun birlikte hazırlamıș olduğu, Gemiadamlarının Tıbbi Açısından İncelenmesine İlişkin Kılavuz, konuya ilişkin detayları düzenlemektedir. Bkz. Guidelines On The Medical Examinations of Seafarers, Sectoral Activities Programme ILO/IMO/JMS/2011/12, International Labor Office, Geneva 2011, https://www.ics-shipping. org/docs/default-source/ILO-MLC-docs/ilo-imo-guidelines-on-the-medical-examinationsof-seafarers.pdf?sfvrsn=4, erişim tarihi, 01.10.2019.

117 Belirtmek gerekir ki, 188 sayılı Sözleşmeye taraf olan Güney Afrika ve Kore gibi bazı ülkelerde balıkçı ve gemiadamı için aranan tıbbi muayene koşulları arasında farklılık oluşturulmamıştır (ILO Handbook For Improving Living And Working Conditions On Board Fishing Vessels, Geneva, 2010, s. 68, https:/www.ilo.org/wcmsp5/groups/public/--ed_dialogue/---sector/documents/publication/wcms_162323.pdf, erişim tarihi, 25.09.2019).

118 Bu yönde bir muafiyet hakk1, Sözleşmenin 4/1- (a) maddesindeki düzenlemenin sonucudur. 
bir sağlık sertifikası olması koşuluyla, gemide çalışmasına sınırlı bir süre veya özel durumlarda tıbbi sertifika alınıncaya kadar izin verebilir (m. 10/3).

Ulusal hukukta konunun düzenleniş biçimini ele alacak olursak, konu doğrudan iş sağlığı ve güvenliğine ilişkin olduğundan, TBK. m.417'de yer alan işçiyi koruma borcu ve 6331 say1lı Kanunu’nda yer alan hüküm uygulama alanı bulacaktır. Esasen anılan Kanun'un 2. maddesinde yer alan, "kamu ve özel sektöre ait bütün işlere ve işyerlerine, bu işyerlerinin işverenleri ile işveren vekillerine, çırak ve stajyerler de dâhil olmak üzere tüm çalışanlarına faaliyet konularına bakılmaksızın uygulanır" hükmü gereği balıkçılık faaliyetini gerçekleştiren tüm çalışanlar 6331 sayılı Kanun kapsamında olacaktır ${ }^{119}$. Buna göre, kanunun 15/2. fikrasında yer alan, "Tehlikeli ve çok tehlikeli sınıfta yer alan işlerde çalışacaklar, yapacakları işe uygun olduklarını belirten sağlık raporu olmadan işe başlatılamaz” hükmü 188 sayılı Sözleşme hükmünü karşılamaktadır. Aynı kanunun 9. maddesine göre, çıkarılan Tehlike Sınıfları Tebliği'nin ${ }^{120}$ ekine göre, denizlerde ve tatlı sularda yapılan balıkçılık faaliyeti "tehlikeli" sınıfta; deniz kabuklularının, yumuşakçalarının toplanması ise "çok tehlikeli" sınıfta sayılmıştır'121. Bu nedenle, tüm balıkçılık faaliyetleri açısından işe uygun olduğuna ilişkin sağlık raporu alınması zorunludur. Öte yandan, gemi adamı olabilmek için aranan genel koşullardan biri de, Gemiadamları ve Kilavuz Kaptanlar Yönetmeliği'nin 42/1-c maddesinde "Sağlık durumunun deniz hizmetine elverişli olduğunu belgelemek," olarak belirlenmiştir. Aynı yönetmeliğin 58. ve 59. maddelerinde gemiadamlarının sağlık yoklamalarının ne şekilde yapılacağı düzenlenmiştir. Buna göre, "Gemiadamları, Sağlık Bakanlığı tarafından yayımlanan Gemiadamları Sağlık Yönergesi hükümlerine göre iki yılda bir periyodik sağlık yoklaması yaptırırlar (Y. m. 58/1). Maddede ifade edilen, Gemiadamları Sağlık

119 Kanunun istisnalarının yer aldığı maddede aksi yönde bir düzenleme bulunmamaktadır. Ancak hatırlatmak gerekir ki, Anayasa Mahkemesinin 14/5/2015 tarihli ve E. 2014/177, K. 2015/49 sayılı kararıyla 2. maddenin (e) fikrasında, "deniz yolu tașımacılığ yapan araçların seyrüsefer hallerinde bu kanun hükümleri uygulanmaz" hükmü, iş güvenliğine ilişkin işveren yükümlülüklerden kurutulma sonucunu doğuracağından yürürlükten kaldırılmıştır.

120 İş Sağlığı ve Güvenliğine İlişkin İşyeri Tehlike Sınıfları Tebliği, RG. 28509, 26.12.2012.

121 Yürürlükten kaldırılmıș olan 15.8.2009 tarihli ve 27320 sayılı Resmî Gazete'de yayımlanan İşyeri Sağlık ve Güvenlik Birimleri ile Ortak Sağlık ve Güvenlik Birimleri Hakkında Yönetmeliğin 57. maddesi uyarınca oluşturulan Tehlike Sınıfı Belirleme Komisyonunun görüşleri doğrultusunda işyerlerinin iş sağlığı ve güvenliği açısından yer aldığ 1 tehlike sınıfları listesine göre deniz avcılığı "tehlikeli işler" arasında yer almaktaydı. 
Yönergesi'nin ${ }^{122}$ kapsamı, 2. maddesinde, “denizde çalışacak gemi adamı adayları ile halen çalışmakta olan gemiadamlarının sağlık durumları ve sağlık işlemleriyle ilgili gereklilikleri, sağlik işlemlerini yürütecek yetkili merkez ile sağlık kuruluşlarına ilişkin işlemleri” olarak belirlenmiştir. Önemle belirtmek gerekir ki, Yönergede 2013 yılında yapılan değişiklikle, daha önce kapsam dışında tutulan balıkçı gemileri artık kapsama alınmıştır ${ }^{123}$. Bu nedenle anılan yönergede düzenlenen esaslar balıkçılar için de uygulama alanı bulacaktır.

Gemiadamları ve Kılavuz Kaptanlar Yönetmeliği’nde, “illk kez gemi adamı olacakların să̆glı yoklamaları ile iki yılda bir tekrarlanan sağglk yoklamaları, Gemiadamları Sağlık Yönergesi hükümlerine göre yetkilendirilen kamu ve özel sağllk kuruluşlarınca yapılır." düzenlemesine yer verildikten sonra, balıkçı gemilerinde çalışanların sağlık yoklamalarının nerede yapılacağı şu şekilde somutlaştırılmıştır; “...balıkçı gemilerinde çalışan gemiadamlarının tabi olacakları să̆llk raporlarl, sürücü olur raporu düzenlemeye yetkili kamu veya özel sağllk kuruluşlarından ${ }^{124}$ veya Săgllk Bakanlığ Türkiye Hudut ve Sahiller Sağllk Genel Müdürlügünün birimlerinden alınır"

Sağlık raporu düzenlenmesinde, dikkate alınan kriter yönetmeliğin 58. maddesinin 4. fikrasında şu şekilde belirlenmiştir; "B sinıfi sürücü belgelerinin düzenlenmesinde esas alınan sağllk şartlarl veya raporun Sağllk Bakanlığ Türkiye Hudut ve Sahiller Sağlık Genel Müdürlüğünden alınması durumunda anılan Genel Müdürlü̈̆̈̈n belirleyeceği standartlar geçerlidir. Göz muayenesinde renk körü olduğu veya gece körlüğ̈̈ olduğu tespit edilenler gemiadamı olamazlar. Balıkçı gemisi güverte tayfası yeterliği dışında, bu madde kapsamında olan gemiadamları, ilk kez gemi adamı olurken ikinci fikra hükümlerine uygun sağlık raporu almak, bu fikra kapsamı dışındaki

${ }_{122}$ Gemiadamları Sağlık Yönergesi 06 Aralık 2013 tarihli ve 10600330-659/9 sayılı Bakanlık Makamı Onayı ile çıkarılmıștır. Bu Yönerge, 25/06/2003 tarihli ve 4908 sayılı Kanunla kabul edilen Uluslararası Çalıșma Örgütünün Gemiadamlarının Sağlık Muayenesine ilișkin 73 say1lı Sözleşmesi, 31.01.2013 tarihinde 6404 sayılı Kanunla kabul edilen yenilenmiş Gemiadamlarının Eğitim, Belgelendirme ve Vardiya Standartları Hakkında Uluslararası Sözleşme (STCW-78)' nin Kural I/9, 1şı̆̆ında hazırlanmıştır.

12305 Ocak 2011 Tarih ve B.10.1.HSS.0.61.00.00/ 01 Sayı Onaylı Gemiadamları Sağlık Yönergesi'nin 2. maddesi şu şekildeydi; "200 Gros Tondan küçük olan gemiler ile balıç̣ı gemilerinde çalıșan gemiadamları hakkında bu Yönerge hükümleri uygulanmaz."

124 "Sürücü ve sürücü adaylarının muayeneleri; Sağl1k Bakanlığına ve üniversitelere bağlı sağlık tesisleri, aile sağlığı merkezleri ve Sağlık Bakanlığınca ruhsatlandırılan özel sağlık kuruluşlarında görevli tabip veya uzman tabip tarafından bu Yönetmelik hükümlerine göre yapılır ve sağlık raporu düzenlenir." Sürücü Adayları ve Sürücülerde Aranacak Sağlık Şartları ile Muayenelerine Dair Yönetmelik, m. 4/1. RG. 26301, 26.09.2006. 
gemilerde çalışmaları halinde ise, Gemiadamları Sağlık Yönergesine göre iki yıllık sağlık raporlarını almak zorundadırlar."

Yönetmeliğin sözü edilen m.58/4 hükmü kanaatimizce karmaşık anlatımı ve B sınıfı sürücü belgesi ile ilişkilendirme yapması nedeniyle eleştiriye açıktır. $\mathrm{Bu}$ durumda yapılması gereken, ilk kez balıkçılık faaliyetine başlayacak bir kişi, aynı zamanda gemiadamı olduğundan dolayı yukarıda bahsedilen mevzuat gereği "gemi adamı olur" içerikli sağlık raporunu "yetkilendirilen kamu ve özel să̆llk kuruluşları"ndan almasıdır.

Ardından İSGK. m. 15 hükmü gereği işyeri hekiminden de aynı içerikli raporu almasının gerekip gerekmediği ortaya konulmalıdır. Kanaatimizce, her ne kadar konuya ilişkin ikincil mevzuatta ayrık düzenleme bulunsa da, İSGK. m. 15/3'deki açık hüküm gereği, işyeri hekiminden sağlık raporu almamak işvereni m. 26/1-f'deki idari para cezasına maruz kalmaktan kurtarmayacaktır. Kald1 ki, aile hekiminden alınan raporla işyeri hekiminden alınan raporu kıyasladığımızda, işyeri hekiminin çalışma ortamına ve koşullarına vakıf olmasından dolayı yapılan işte sağlığı etkileyebilecek hususları daha iyi öngörebilme olasılığı daha yüksek olacaktır. Nihayet, Gemiadamları Sağlık Yönergesi'nde, bu yönergeye göre alınan raporların İSGK açısından da geçerli olacağını gösteren açık bir hüküm de bulunmamaktadır.

Tıbbi muayenenin niteliklerine ilişkin açıklamalar Sözleşmenin 11. ve 12. maddelerinde yapılmıştır. İlk olarak, taraf devletlere, tıbbi muayenenin niteliği, verilecek sağlık raporlarının şekli ve içeriği, sağlık raporu veren doktorun bu raporu vermeye yetkili uzman doktor olduğunun ve bu konuda mesleki bağımsızlığa sahip olduğunun, tıbbi muayene sıklığı ve tıbbi sertifikaların geçerlilik süresinin, sağllk raporu alamayan veya sadece sınırlı işler bakımından sağlık raporu almış olan kişinin ikinci bağımsız bir doktor tarafından yeniden değerlendirilme yapılmasını talep hakkı verilmesi ve nihayet diğer ilgili şartları içermesi gerektiği yönünde bir yükümlülük getirilmiştir.

Görüldüğü gibi Sözleşme tıbbi muayeneye ilişkin çerçeveyi belirledikten sonra detaylarını belirleme yetkisini taraf devletlere bırakmışıtır. 6331 sayılı Kanun gereği yapılması gereken (sağlık raporu alınması) tıbbi muayeneye ilişkin detaylara bakıldığında, öncelikle sağlık raporunun hangi doktor tarafindan verileceğine ilişkin olarak, 15/3. maddesinde, "Bu Kanun kapsamında alınması gereken sağlık raporları işyeri hekiminden alınır. 50'den az çalışanı bulunan ve az tehlikeli işyerleri için ise kamu hizmet 
sunuculart veya aile hekimlerinden de alinabilir." demek suretiyle yetkili doktor olarak öncelikle işyeri hekimini, daha sonra aile hekimi veya kamu sağlık hizmet sunucularını işaret etmiştir. Balıkçılık faaliyeti az tehlikeli sınıfta olmadığından, iş sağlığı ve güvenliği mevzuatı gereği çalışan sayısına bakılmaksızın tüm sağlık raporlarının işyeri hekiminden alınması zorunluluğu ortaya çıkmaktadır ${ }^{125}$. Burada hangi işyerlerinde işyeri hekimi bulunmaktadır sorusuna yanıt vermek gerekmektedir. Tehlikeli ve çok tehlikeli sınıfta yer alan balıkçı gemisi/teknesi açısından bakıldığında herhangi bir çalışan sayısı alt sınırı aranmadığından, tüm balıkçılık faaliyeti yürüten işyerlerinde mutlaka işyeri hekimi bulunması zorunludur. İş güvenliği uzmanlığında olduğu gibi sektörel bir işyeri hekimliği sistemimizde henüz söz konusu olmadığından, işyeri hekimi belgesine sahip herhangi bir hekim, çalışan sayısı ve tehlike sınıfina göre en az İşyeri Hekimi ve Diğer Sağlık Personelinin Görev, Yetki, Sorumluluk ve Eğitimleri Hakkında Yönetmelik' in ${ }^{126} 12$. maddesinde belirlenen süreler kadar çalışmalıdır.

Sağlık raporunun geçerlilik süresi ise, İş Sağlı̆̆ı ve Güvenliği Kanunu'nun 15. maddesinde, "İş değişikliği durumunda, İş kazası, meslek hastalı̆̆1 veya sağlık nedeniyle tekrarlanan işten uzaklaşmalarından sonra işe dönüşlerinde talep etmeleri hâlinde, İşin devamı süresince, çalışanın ve işin niteliği ile işyerinin tehlike sınıfına göre Bakanlıkça belirlenen düzenli aralıklarla" olmak üzere belirlenmiştir. Bakanlıkça belirlenen periyot ise, İşyeri Hekimi ve Diğer Sağlık Personelinin Görev, Yetki, Sorumluluk ve Eğitimleri Hakkında Yönetmelik'in 9/c-3. maddesinde, "tehlikeli sinuftaki işlerde en geç üç yılda bir, çok tehlikeli sinuftaki işlerde en geç yılda bir, özel politika gerektiren grupta yer alanlardan çocuk, genç ve gebe çalışanlar için en geç altı ayda bir defa olmak üzere periyodik muayene tekrarlanır. Ancak işyeri hekiminin gerek görmesi halinde bu süreler kısaltılır." biçiminde belirlenmiştir.

188 sayı1ı Sözleşme'nin 12. maddesinde sağlık raporunun (sertifikanın) geçerlilik süresine ilişkin özel bir düzenlemeye yer verilerek, 18 yaşından büyük balıkçılar açısından 2 yıllık bir süre öngörülürken, küçükler bakımından bu süre 1 yıl ile sinırlandırılmıştır (m. 12/2). Ayrıca belirlenen süreler, yolculuk esnasında sona ererse, sertifikanın bu yolculuğun sonuna kadar yürürlükte kalacağına da hükmedilmiştir (m. 12/3). Gemiadamları ve Kılavuz

125 Çalışanın işe uygunluğuna en iyi o işyerinin çalışma koşullarını bilen işyeri hekiminin karar vereceğinden sağlık raporlarının işyeri hekiminden alınmasına ilişkin düzenlemenin isabetli olduğu yönünde, ÖZDEMIR, s. 260.

${ }^{126}$ RG. 28713, 20.07.2013. 
Kaptanlar Yönetmeliği’ne göre, periyodik sağlık muayenesi en geç iki yılda bir, onsekiz yaşından küçüklerinki ise, Gemiadamları Sağlık Yönergesi ve 77 Sayılı Çocukların ve Gençlerin İşe Elverişlilik Yönünden Sağlık Yoklaması Olmalarına İlişkin ILO Sözleşmesi hükümleri göz önüne alınarak her yıl yapılır (Y. m. 59/1). ILO'nun 188 sayılı Sözleşmesine de uygun olan bu periyodik muayeneler, İSGK'da daha farklı düzenlenmiş olduğundan, bu konuda da her iki mevzuata göre ayrı ayrı muayene yapılması gerektiği sonucu ortaya çıkmaktadır. Bu sonucun, olması gereken hukuk açısından isabetli olsa da, uygulayıcılar açısından pratik bir çözüm olmadığı ortadadır. Bu nedenle kanaatimizce, mevzuatta düzenlemeye gidilerek, İSGK'da yer alan sağlık gözetimine ilişkin hükümlerin çalışan lehine olan özel mevzuat hükümleri varken uygulanmaması yönünde bir sonucuna varılabilir.

Sözleşmede belirtilen, alınan raporlara itiraza ilişkin hüküm de İSGK.'nun 15/3. maddesinin son cümlesinde, "Raporlara itirazlar Sağlık Bakanlığ tarafindan belirlenen hakem hastanelere yapılır, verilen kararlar kesindir." denilmek suretiyle mevzuatımızda karşılık bulmuştur. Gemiadamları Sağlık Yönergesi'nin 15/3. maddesinde de verilen sağlık raporuna karşı gemi adamı adaylarının, gemiadamlarının, liman başkanlıklarının, yetkili tabiplerin ve Genel Müdürlüğün itiraz hakkı olduğu belirtilerek, itiraz prosedürü detaylı olarak düzenlenmiştir.

Tibbi muayeneye ilişkin olarak 188 sayılı Sözleşmenin 12. maddesinde, bazı durumlar için ek koşullar kabul edilmiştir. Bunlar; "24 metre uzunluğunda ve üstü bir balıkçı teknesinde veya normalde üç günden uzun süre denizde kalan bir teknede; Bir balıkçının sağlık sertifikasının, asgari olarak şunları da içermesi gerektiği yönündedir; (a) ilgili balıkçının işitme duyusu ve görüşü, balıkçının gemi üzerindeki görevlerini yerine getirmek için yeterli olduğu, (b) balıkçı, denizde faaliyet gösterdiğinde ağırlaşması muhtemel herhangi bir tıbbi durumdan muzdarip olmadığını veya gemideki diğer kişilerin güvenliğini veya sağlığını tehlikeye atmayacağını belirten hükümler içermelidir.

\section{SONUÇ}

Balıkçılık, üç tarafı denizlerle çevrili olan ülkemiz açısından gerek ekonomiye doğrudan katkısı gerekse istihdam sağlaması açısından önemli bir sektördür. Ancak bu sektördeki işçilerin çalışma yaşamından kaynaklanan haklarını düzenleyen detaylı mevzuat hükümleri bulunmadığı gibi var olan düzenlemeler de mevzuatımızda dağınık bir biçimde yer almaktadır. Sektörün su ürünleri üreticiliği içinde yer alması, balıkçı kavramının kimleri kapsadığını 
belirlemede de güçlüklere yol açmaktadır. Çalışmamızda balıkçılık gerek denizde gerekse iç sularda balıkçı gemi veya tekneleriyle yapılan balık avcılığ 1 olarak kabul edilmiştir.

Çalışmamızda yapılan tespitlerden ilki, balıkçılık yapan işçi statüsünde çalışanların hangi kanun kapsamına dahil olduklarıdır. Bu konuda varılan sonuç, balıkçılık sektöründe çalışanların dahil olduğu kanun kapsamını belirlerken, öncelikle Deniz İş Kanunu kapsamında olup olmadıklarının değerlendirilmesi gerektiği, bu kapsamda değillerse ve gerçekleştirdikleri faaliyet tarım işinden de sayılmıyorsa, Türk Borçlar Kanunu'nun uygulanacağ 1 yönündedir. Balık avcılığı İş Kanunu'nda tarım işi olarak kabul edildiğinden, ellinin üzerinde işçi çalıştırılan tarım işletmeleri de İş Kanunu kapsamında olduğundan, istisnai nitelikte olsa da İş Kanunu kapsamına giren balıkçılar da olacaktır. Böylece balıkçılık sektöründe çalışan Deniz İş Kanunu, İş Kanunu ve Türk Borçlar Kanunu kapsamına dahil olan üç farklı çalışan grubu ortaya çıkmaktadır. Bunun olumsuz sonuçlarından kurtulmak için 2006 Deniz Çalışma ILO Sözleşmesinin kabulünün ardından güncellenmesi beklenen Deniz İş Kanunu'na balıkçılık faaliyetiyle uğraşan tüm çalışanları dahil etmek isabetli olacaktır.

Çalışmamızın kapsamında 188 sayılı ILO Balıkçılık İstihdam Sözleşmesi de yer almaktadır. Bu sözleşme 2017 yılı itibariyle taraf ülkeler açısından yürürlük kazanmış olup, ülkemiz henüz bu sözleşmeye taraf olmadığından, iç hukukumuzda uygulanmamaktadır. Belirtmek gerekir ki, ülkemiz geçmiş yıllarda imzalanan balıkçılıkla ilgili diğer ILO sözleşmelerine de taraf değildir. Denizcilik sektörüyle ilgili temel ILO Sözleşmelerinden biri sayılan 2006 ILO Deniz Çalışma Sözleşmesi'ni onaylayan ülkemizin, balıkçılık sektörüyle ilgili çekingen davranma gerekçesini anlamak güçtür. Deniz Çalışma Sözleşmesi'nin balıkçılık sektörünü kapsam dışı tutma kararı karşısında, 188 sayılı Balıkçılık İstihdam Sözleşmesi'ne duyulan ihtiyaç daha da belirgin hale gelmektedir. Sözleşmenin çalışmamızda inceleyebildiğimiz hükümlerini deniz iş mevzuatımızdaki kurallarla kıyasladığımızda, özellikle ikincil mevzuat olarak karşımıza çıkan konuya ilişkin yönetmeliklerin genellikle AB Direktiflerine uygun olduğu görülmektedir. Bu durumda kanaatimizce, Deniz İş Kanunu'nda yapılması öngörülen değişiklikle, bu kanuna öncelikle tüm balıkçıların kanun kapsamına alınmasına ilişkin hüküm konulması, ardından 188 say1lı Sözleşmedeki hükümlerin Deniz İş Kanunu'muza dahil edilmesi isabetli olacaktır. 


\section{KAYNAKÇA}

AKTAY, Nizamettin/ARICI, Kadir/SENYEN KAPLAN, Emine Tuncay: İş Hukuku, 6. Bask1, Gazi Kitabevi, Ankara 2013.

ALGANTÜRK LIGHT, Didem: "Deniz İş Sözleşmesi 2006 Hakkında İnceleme ve Değerlendirme", Erzincan Üniversitesi Hukuk Fakültesi Dergisi, 20. Kuruluş Y1lı Armağanı, Cilt 11, Sayı 1-2, y1l 2007, s. 269278.

ASTARLI, Muhittin: İş Hukukunda Çalışma Süreleri, 1. Baskı, Turhan Kitabevi, Ankara 2008.

BAKIRCI, Kadriye: Çocuk ve Genç İşçilerin Haklarının Korunması, 1. Bask1, Beta Yayınevi, İstanbul 2004.

BAYRAM, Fuat: "AB İlerleme Raporlarındaki Tespit ve Eleştiriler Çerçevesinde Türk İş Hukuku Mevzuatında Yapılması Gereken Değişiklikler”, Legal İş ve Sosyal Güvenlik Hukuku Dergisi, Y11 2007, Say1 13, s. 51-96.

BEDÜK, Mehmet Nusret: Deniz İş Sözleşmesi, 2. Baskı, Ekin Yayınevi, Bursa 2012.

CARBALLOPI $\sim$ NEIRO, Laura: International Maritime Labor Law, International Max Planck Research School (IMPRS) for Maritime Affairs at the University of Hamburg, 1. Edition, Springer-Verlag, Berlin Heidelberg, 2015.

CENTEL, Tankut: "Eşitlik İlkesi Bağlamında Tarım ve Orman İşleri”, Çimento İşveren Dergisi, Mayıs 2014, s. 10-17.

CENTEL, Tankut: İş Hukuku Cilt 1, Bireysel İş Hukuku, 1. Bası, Beta Yayınevi, İstanbul 1994.

CiN, Turgay: "Devletlerarası Hukukta Balıç̧1lk", Dokuz Eylül Üniversitesi Hukuk Fakültesi Dergisi Cilt 8, Sayı 1, 2006, s. 21-45.

ÇELIK, Nuri /CANIKLIOĞLU, Nurşen/CANBOLAT, Talat: İş Hukuku Dersleri, Yenilenmiş 32. Bası, Beta Yayınevi, İstanbul 2019.

DOĞANYILMAZ ÖZBİLGİN, Yeliz /TOK Volkan,: "Mersin Körfezi Trol Balıkçılarının Denizde Güvenlik Farkındalıklarının İncelenmesi”, Ege Su Ürünleri Dergisi, Cilt 34, Say1 2, Y11 2017, s. 139-144.

DÜNDAR, Esra: Uluslararası Düzenlemeler ve AB Çerçevesinde Deniz 
İş Hukukunda Gemi Adamlarının Çalışma Süresi, 1. Baskı, Seçkin Yayınevi, Ankara 2012.

EMIROĞLU, Mecdi: “Türkiye'nin Su Ürünleri Üretimi”, Ankara Üniversitesi Dil ve Tarih-Coğrafya Fakültesi Dergisi, S. 31/1-2, Y. 2018,s.77-146.

GÖKÇE, Erdal: “Deniz İş Kanunu'nun Hukuk Sistemindeki Yeri ve Niteliği”, İstanbul Barosu Dergisi, Cilt 82, Say1 2, Y11 2008, s. 739-758.

HYDER, K./RADFORD, Z./PRELLEZO, R/WELTERSBACH, Lewin, WC/ ZARAUZ, L,/FERTER, K./RUIZ, J./TOWNHILL, B./MUGERZA, E./ STREHLOW, Hv.: General For Internal Polıcies Policy Department for Structural and Cohesion Policies Fisheries,EuropeanmParli amentmDirectorate-MSFCMA,2017,http://www.europarl.europa. eu/RegData/etudes/STUD/2017/601996/IPOL_STU(2017)601996_ EN.pdf, erişim tarihi 31.09.2019.

KAR, Bektaş: Deniz İş Hukuku Ders Kitabı, 5. Baskı, Yetkin Yayınevi, Ankara 2014 (Deniz İş).

KAR, Bektaş: “6098 Sayılı Türk Borçlar Kanunu’nun 854 Sayılı Deniz İş Kanunu'na Etkisi, İstanbul Üniversitesi Hukuk Fakültesi Mecmuası, Cilt 74, Say1 2, Y11 2014, s. 167-176, (TBK).

KARAN Hakan/ AKIN, Levent: "Gemi Adamları Bakımından İş Güvenliği ve İşçi Sağlığı”, Prof. Dr. E. Çetingil ve Prof. Dr. R. Kender'e 50. Birlikte Çalışma Yılı Armağanı, İstanbul 2007, s. 718-729.

MOLLAMAHMUTOĞLU, Hamdi/ ASTARLI, Muhittin/ BAYSAL, Ulaş: İş Hukuku Ders Kitabı, Cilt 1, Güncellenmiş 3. Baskı, Lykion Yayınevi, Ankara 2019.

NARMANLIOĞLU, Ünal: İş Hukuku Ferdi İş İlişkileri I, 4. Baskı, Beta Yayınevi, İstanbul 2012.

ÖZKARACA, Ercüment/ÜNAL, Canan: "Küçüklerin Çalışmasına İlişkin Yasak ve Sınırlamalar ile Bunlara Aykırılık Halinde İş Sözleşmesinin Geçersizliği Sorunu", Marmara Üniversitesi Hukuk Fakültesi Hukuk Araştırmaları Dergisi, Özel Sayı, Prof. Dr. Ali Rıza Okur’a Armağan, Cilt 20, Say1 1, Y11 2014, s. 355-410.

SÜZEL, Cüneyt: "Gemi Adamlarının Yurda İade Masraflarına İlişkin Deniz İş Kanunu ve ILO Sözleşmelerinin Hükümlerinin Karşılaştırılması”, İş 
Hukukunda Yeni Yaklaşımlar II, İstanbul 2018, s. 175-246.

SÜZEK, Sarper: İş Hukuku, 2. Bask1, Beta Yayınevi İstanbul, 2005.

ŞAHİN, Güven: "Türkiye'de Yitirilen Bir İktisadi Faaliyet: Süngercilik", Akademik Bakış Dergisi, Sayı 39, Kasım - Aralık 2013, s. 1-22.

TANTOĞLU, Gurur: Balıkçı Gemilerinde Yapılan Çalışmaların İş Sağlığı ve Güvenliği Yönünden Değerlendirilmesi, T.C. Çalışma ve Sosyal Güvenlik Bakanlığı İş Sağlığı ve Güvenliği Genel Müdürlüğü, Uzmanlık Tezi, 2016.

TATAR, Veysel/ADALI Mehmet Rıza /ÖZER, Meriç Burçin: "Balıkçılık Sektörünün İş Sağlığı ve Güvenliği Yönünden Değerlendirilmesi”, Akademik Sosyal Araştırmalar Dergisi, Yı1 6, Sayı 74, Temmuz 2018, s. 513-526.

ULUKAN, Umut: "Balıklar, Tekneler ve Tayfalar: Türkiye'de Balıkçılık Sektöründe Çalışma ve Yaşam Koşulları”, Çalışma ve Toplum Dergisi, 2016/1, Say1 48, s.115-141.

YENIGÜN, M. Cüneyt: (Yayınlanmamış Doktora Tezi) Askeri, Hukuki, Ekonomik ve Dış Politik Açılardan Türk Deniz Politikası (Bir Uluslararası İlişkiler Çalışması), İstanbul 1997.

YÜREKLİ, Sabahattin: "Deniz İş Kanunu'nun Yer İtibariyle Kapsamı", Atatürk Üniversitesi Erzincan Hukuk Fakültesi Dergisi, Cilt 9, Say1 1-2, Y11 2005, s. 613-631.

\section{İnternet Kaynakları:}

ILO International Labour Conference 92. Session 2004 Report V (1), Conditions Of Work In The Fishing Sector-A Comprehensive Standard (A Convention Supplemented By A Recommendation) On Work İn The Fishing Sector,https:/www.ilo.org/global/publications/ ilo-bookstore/order, online/books/WCMS_PUBL_9221130398_EN/ lang--en/index.htm., erişim tarihi 26.08.2019.

ILO Handbook For Improving Living And Working Conditions On Board Fishing Vessels, Geneva, 2010, s. 68, https://www.ilo.org/wcmsp5/ groups/public/---ed_dialogue/---sector/documents/publication/ wcms_162323.pdf, erişim tarihi, 25.09.2019.

ILO Work in Fishing Convention and Recommendation, 2007 Action Plan 2011-2016, International Labour Office Genova, 2011. https://www. 
ilo.org/wcmsp5/groups/public/---ed_dialogue/---sector/documents/ publication/wcms_161220, erişim tarihi, 04.10.2019.

ILO Working Paper No. 315, "The Flexibility Clauses Of The Work in Fishing Convention, 2007 (No. 188)".Decent Working Conditions Safety and Social Protection- Work in Fishind Convention No:188, Recommendation 199 Booklet 2007, https://www.ilo.org/sector/ Resources/publications/WCMS_161209/lang--en/index.htm, erişim tarihi, 29.08.2019.

IMO'dan Haberler İMEAK Deniz Ticaret Odas1 Eylül (2017) Bülteni, http://www.vda.org.tr/upload/duyuru/Ey1\%C3\%BC1\%20 b\%C3\%BClten_2017.pdf, erişim tarihi, 29.08.2019.

İstanbul ve Marmara, Ege, Akdeniz, Karadeniz Bölgeleri Deniz Ticaret Odas1 Deniz Sektörü Raporum2017,İstanbul2018,s.272,https://www. denizticaretodasi.org.tr/Media/SharedDocuments/sektorraporu/2017 sektor_tr.pdf, erişim tarihi 26.08.2019.

Report of the FAO Workshop On Child Labour In Fisheries And Aquaculture In Cooperation With ILO, Rome, 14-16 April 2010, s.3, http://www. fao.org/3/i1813e/i1813e00.htm, erişim tarihi 13.09.2019.

Subsistence Fishing, World Fisheries Trust 2008, http://www.worldfish.org/ GCI/gci_assets_moz/Fact\%20Card\%20-\%20Subsistence\%20Fishing. pdf, erişim tarihi, 26.08.2019.

T.C. Tarım ve Orman Bakanlığı Su Ürünleri İstatistikleri, https://www.tarimorman.gov.tr/B S GM/Belgeler/ Icerikler/Su $\% 20 \% \mathrm{C} 3 \% 9 \mathrm{Cr} \% \mathrm{C} 3 \% \mathrm{BCnleri} \% 20$ Veri $\% 20$ ve $\% 20$ D \% C 3\% B 6 k \% C 3 \% B C m an 1 ar \% C 4\% B $1 /$ S u $\% \mathrm{C} 3 \% 9 \mathrm{Cr} \% \mathrm{C} 3 \% \mathrm{BCnleri}-\% \mathrm{C} 4 \% \mathrm{~B} 0$ statistikleri.pdf, erişim tarihi 28.08.2019. 
